\title{
CONTRIBUTIONS TO THE HYDROLOGY OF THE UNITED STATES, 1926
}

\author{
N. C. Grover, Chief Hydraulic Engineer
}

\section{GEOLOGY OF NO. 3 RESERVOIR SITE OF THE CARLSBAD IRRIGATION PROJECT, NEW. MEXICO, WITH RESPECT TO WATER-TIGHTNESS}

\author{
By Oscar E. Meinzer, B. Coleman Renick, and Kirk Bryan
}

\section{SUMMARY OF CONCLUSIONS AND RECOMMENDATIONS}

Investigation of the character and structure of the rocks in the vicinity of the No. 3 reservoir site and of the ground-water conditions in these rocks has led inevitably to the conclusion that there is danger of serious leakage from the proposed reservoir. The rocks underlying the reservoir site and adjacent to it consist largely of cavernous limestone and gypsum. At the dam site and in much of the area immediately east and southeast of the reservoir site the ground-water level in these rocks is below the river level, showing that water which enters the openings in the rocks in parts of this area is drained away from the river to some other locality where it finds a lower outlet.

At least a large part of the water that leaks out of the McMillan Reservoir, amounting at times to as much as 300 second-feet, finds its way through a system of underground channels to a locality 3 or 4 miles downstream, r.here it reappears in springs at an elevation about 35 feet below the high flow line (elevation 3,260 feet) of the proposed reservoir. If these springs are submerged the water in the system of underground channels will be impounded and may escape into cavernous rock having a low water table immediately to the south.

As gypsum crops out at low levels in the reservoir site below the spring area there is danger that leaks will develop in the lower part of the reservoir somewhat similar to those that exist in the lower part of the McMillan Reservoir. The outcrops of gypsum are less extensive than those in the McMillan Reservoir but the water would be under greater head. Such leaks would tend to become more serious in time, as the gypsum is dissolved and eroded away and the underground channels are enlarged. In all probability there would be no practicable means of stopping these leaks.

Much of the water that would escape either by reversal of the springs or through sink holes in the lower part of the reservoir would probably not return to the surface until it reached some point below the Avalon Reservoir. 
It is, of course, possible that the rocks underlying the proposed reservoir and bordering the communicating system of underground channels are tight enough at all points to prevent serious leakage from the reservoir into the adjacent cavernous rocks with low water table. However, the known conditions are much less favorable here than in the Avalon Reservoir, which is apparently perched above the ground-water table, because of the outcrops of gypsum and cavernous limestone that exist in the No. 3 site and because of the high head of water in the proposed reservoir.

The conclusion has therefore been reached that the risk due to probable leakage is too great to warrant the construction of a dam at the No. 3 site designed to impound water to the elevation of 3,260 feet or to any height approaching that elevation.

\section{INTRODUCTION}

\section{IOCATION AND SIZE OF PROPOSED RESERVOIR}

Reservoir site No. 3 of the Carlsbad irrigation project lies several miles north of Carlsbad, N. Mex., in T. 20 S., R. 26 E., and T. 21 S., Rs. 25 and 26 E. (See fig. 1.) It extends along Pecos River for a distance of about 9 miles. The dam site is in sec. 6, T. 21 S., R. 26 E., at a point where the river at low stages is about 3,190 feet above sea level. If the dam is built to the height originally proposed, the flow line, or surface of the water when the reservoir is full, will be about 3,260 feet above sea level, and an area of 8 square miles will be submerged, as shown on the maps. (Fig. 1 and pl. 1.) At this elevation the capacity of the reservoir will be about 90,000 acre-feet. The area and capacity of the reservoir with the flow line at several levels are about as follows:

Area and capacity of the proposed Reservoir No. I at several levels

\begin{tabular}{|c|c|c|c|}
\hline \multicolumn{2}{|c|}{ Elevation } & & \\
\cline { 1 - 2 } $\begin{array}{c}\text { Feet above } \\
\text { river level } \\
\text { at dam site }\end{array}$ & $\begin{array}{c}\text { Feet above } \\
\text { sea level }\end{array}$ & Area & Capacity \\
\hline & & \\
\hline 30 & & & \\
& 3,220 & $4 c r e s$ & Acre-feet \\
50 & 3,230 & 450 & 4,000 \\
60 & 3,240 & 1,900 & 11,000 \\
65 & 3,250 & 3,200 & 50,000 \\
70 & 3,255 & 4,000 & 67,000 \\
& 3,000 & 90,000 \\
\hline
\end{tabular}

Reservoir site No. 3 lies immediately downstream from the McMillan Reservoir, which leaks badly, and almost immediately upstream from the Avalon Reservoir, which holds water without appreciable loss. The spillways of the McMillan Reservoir are at an elevation of about 3,286 feet or about 26 feet above the high flow line of No. 3. The spillway of the Avalon Reservoir is at an elevation of about 3,177 feet, which is 10 to 15 feet below the river level at the No. 3 dam site. 


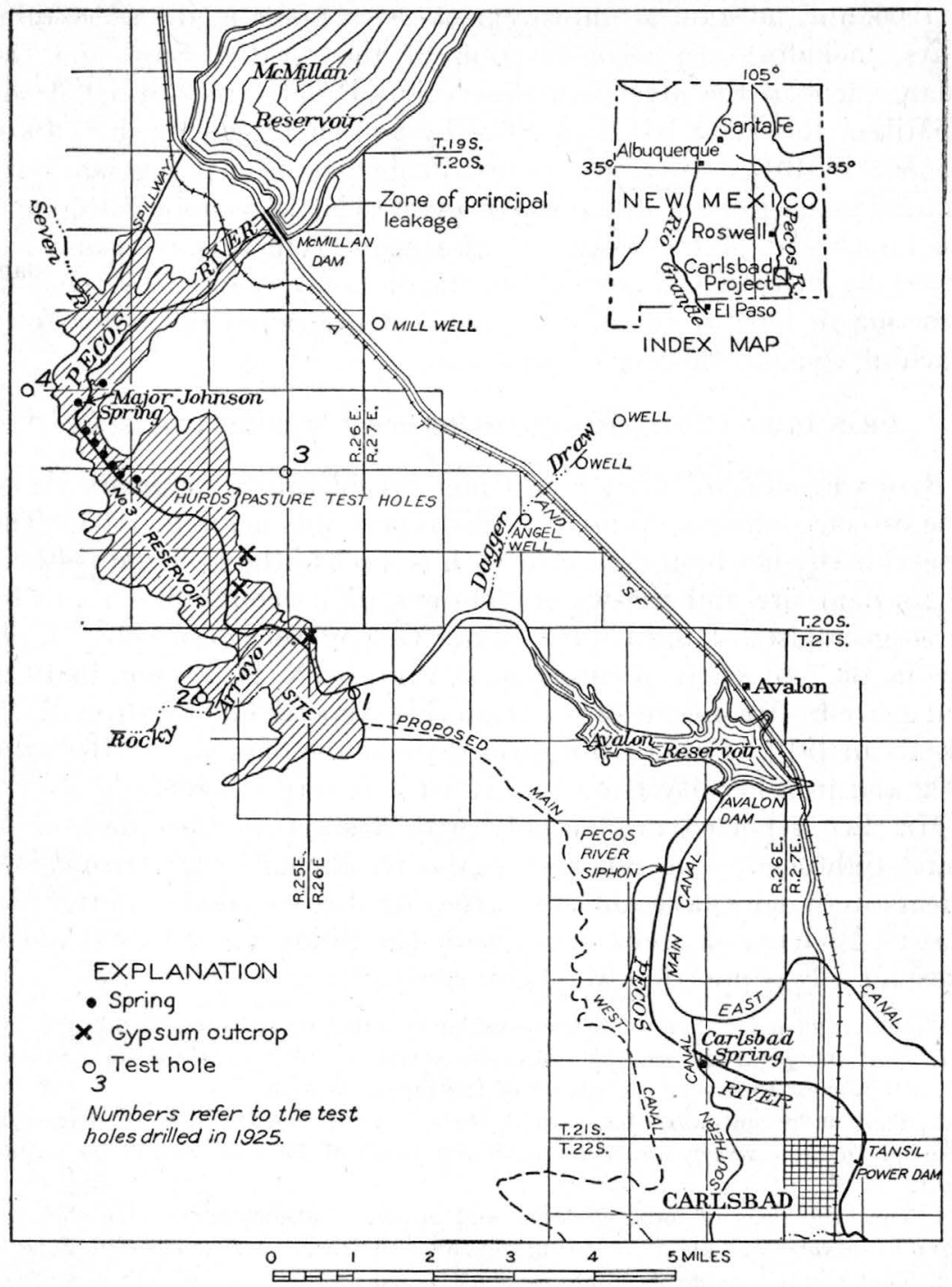

Figure 1.-Map of a part of the Carlsbad irrigation project, New Mexico, showing location of No. 3 reservoir site

\section{HISTORY OF THE PROJECT}

The Carlsbad project was started by private interests in 1888 and was developed in virtually its present general form prior to 1904. At that time impairment of the McMillan Reservoir by silting and increased leakage, destruction of the Avalon Dam, and financial difficulties led to the agitation for rehabilitation by the United States. The project was taken over by the United States Reclamation Service 
in 1906, and substantial improvements were made in the succeeding years, including the reconstruction of the Avalon Dam and the enlargement of the McMillan Reservoir. Progressive silting of the McMillan Reservoir has been offset by two enlargements since 1904, the last in 1915. In recent years silting has been appreciably arrested by the growth of tamarisk (salt cedar, Tamarix gallica) at the upper end of the reservoir. Leakage from this reservoir has gradually increased, though it was temporarily reduced by the construction in 1909 of an embankment that prevented the water from reaching some of the worst sink holes. ${ }^{1}$

\section{PREVIOUS INVESTIGATIONS OF THE RESERVOIR SITE}

Reservoir site No. 3 has been under consideration for many years. The 5-foot contour map used in this report was made in 1905 . The reservoir site has been examined with respect to the geologic features of its dam site and the water-tightness of its containing rocks by three geologists of the United States Geological Survey-by W. T. Lee in 1905, by G. B. Richardson in 1911, by N. H. Darton in 1922, and again by Mr. Lee in 1923. It was also reported on by Prof. E. M. Skeats in 1910. Core drilling was done at the dam site in 1905 and 1922 and in a locality known as Hurd's pasture in 1905.

Mr. Lee reported unfavorably with respect to the question of water-tightness. The reports by Messrs. Richardson, Darton, and Skeats were more favorable, but after Mr. Lee's second investigation Messrs. Richardson and Darton made the following joint statement, substantially supporting Mr. Lee's conclusions :

We agree with Mr. Lee as to these major conclusions set forth in his report:

1. That the pervious beds are sufficiently well blanketed at the dam site of No. 3 Reservoir to assure the safety of the proposed dam.

2. That it is unlikely that No. 3 Reservoir, if constructed as originally planned to hold water under a maximum head of 70 feet, would be watertight.

3. That the beds of salt, gypsum, and cavernous limestone under the proposed reservoir and about it, being pervious to water, are sources of danger.

4. That a small reservoir might be constructed at No. 3 site which, in spite of possible leakage, would be useful in the regulation of flood water.

\section{PRESENT INVESTIGATION AND REPORT}

The present report and recommendations are based on a field examination made by the authors in July and August, 1925. In accordance with a recommendation of the board of surveys and

1 The information given in the above paragraph is taken from the report of Ferd. Bonstedt and E. B. Debler, submitted in 1923. See also Davis, A. P., Irrigation works constructed by the United States Government, pp. 225-230, New York, 1917; Why some irrigation canals and reservoirs leak : Eng. News-Record, vol. 8, pp. 663-665, 1918. 


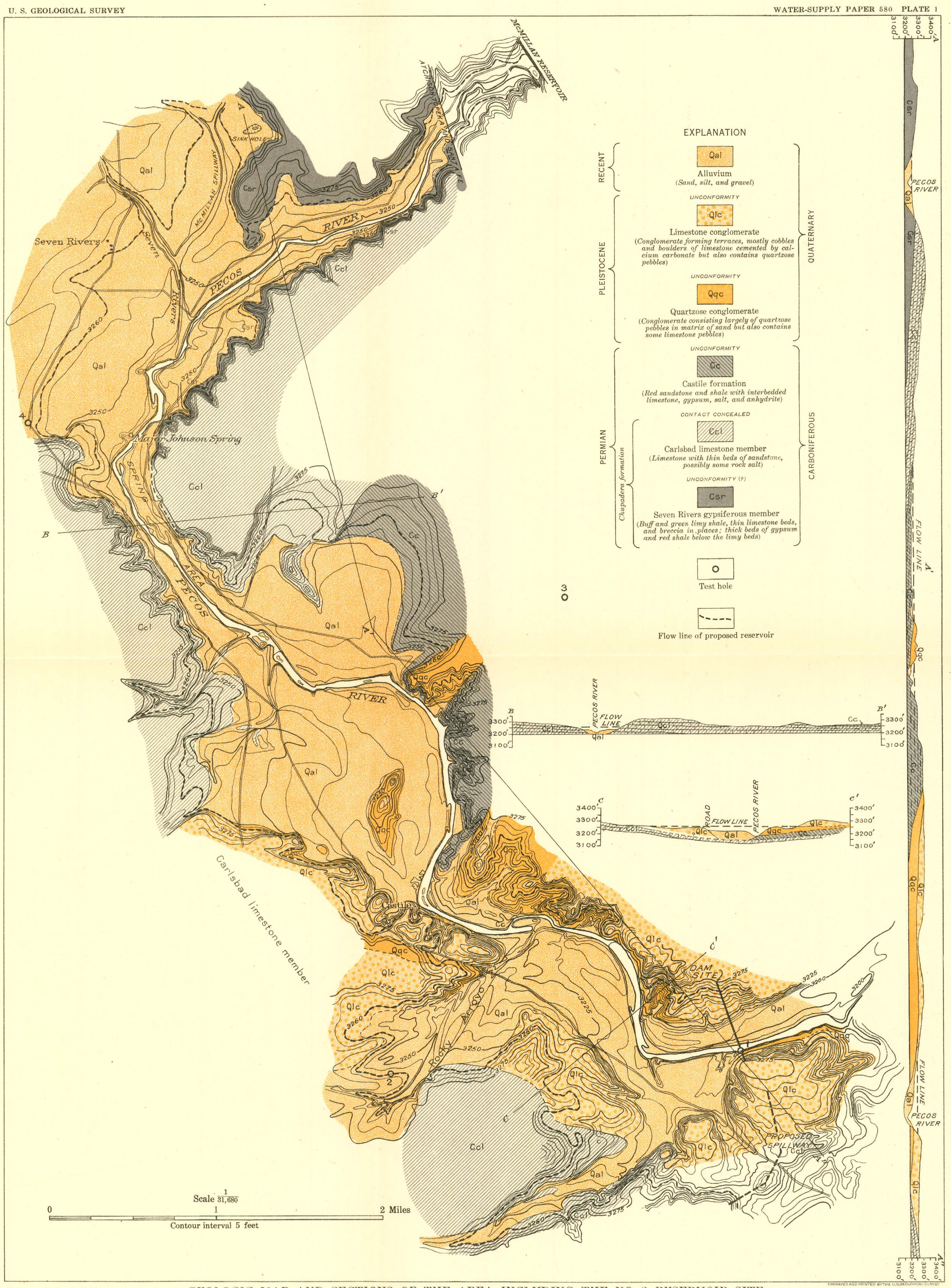


adjustments that proper and complete geologic surveys be made of this reservoir site, the Bureau of Reclamation in financial cooperation with the Carlsbad Water Users' Association undertook the work. As provided in a letter from Dr. Elwood Mead, Commissioner of Reclamation, to the Director of the United States Geological Survey, dated May 4, 1925, this new examination was to be made by geologists who had not previously reported on this reservoir, and all salary and expenses were to be paid out of the cooperative funds provided under the terms of a contract between the Bureau of Reclamation and the Carlsbad Water Users' Association. Mr. Meinzer, geologist in charge of the ground-water division of the Geological Survey, was placed in control of the work and was assisted by Mr. Renick. Mr. Renick spent about three weeks and Mr. Meinzer about two weeks in the field. Mr. Bryan spent two days in the field with Mr. Meinzer.

At the conclusion of the field investigation it was recommended that four test holes be drilled in proximity to the reservoir site for the purpose of determining the depth to ground water. This drilling and the testing of the ground-water conditions were carried out under the efficient supervision of Mr. J. R. Yates, of the United States Bureau of Reclamation. Mr. Renick returned to Carlsbad for a few days in October, 1925, to examine the drilling operations and to witness some of the ground-water tests.

The report was prepared chiefly by Messrs. Meinzer and Renick, most of the section relating to geology being written by Mr. Renick and most of the rest of the report by Mr. Meinzer. All three authors concur in the conclusions and recommendations.

As the previous reports indicate that the rocks at the dam site are sufficiently strong to support a dam with a relatively broad base of the rock-fill type, such as is proposed, the question of the strength of the rocks at the dam site was not reopened in the present examination, the investigations being confined to the question of the water-tightness of the proposed reservoir.

The authors are greatly indebted to Mr. L. E. Foster, superintendent of the Carlsbad project, and to Mr. J. R. Yates, hydraulic engineer, for their interest and help. The engineering and hydrometric data used in this report were largely furnished by these two engineers of the Bureau of Reclamation.

\section{TOPOGRAPHY}

From Roswell to the vicinity of Seven Rivers Pecos River flows near the east side of a wide alluvial plain that slopes very gently from the western uplands and is bordered on the east by low bluffs. The river occupies a shallow trench in this plain until it 
reaches the McMillan Reservoir, which lies in the southeast corner of the plain. On the east and south of the reservoir high cliffs rise almost from the river bank.

South of Seven Rivers the Pecos leaves the broad plain and flows between uplands of moderate relief. This constriction of the valley is due to the outcrop of resistant limestone which the river crosses south of Seven Rivers, within the No. 3 reservoir site. In most of its course through the reservoir site the river occupies a narrow trench with precipitous banks, 15 to 30 feet high, cut in a low terrace that occupies a large part of the floor of the reservoir site. Narrow and precipitous but shallow trenches or gullies have also been cut in this terrace by Seven Rivers, Rocky Arroyo, and some of the smaller streamways. This low terrace is bordered by remnants of two older and higher terraces, which stand about 75 feet and 150 feet or more above the river. The top of the 75-foot terrace is for the most part above the flow line of the proposed reservoir. These three terraces represent three different levels at which the river flowed in the past.

\section{GEOLOGY}

\section{STRATIGRAPHY}

\section{FORMATIONS INCLUDFD}

The rocks in the No. 3 reservoir site are of two kinds-(1) old rocks that have been deposited over extensive areas of the region in basins of water, and (2) younger conglomerate, gravel, sand, and silt that have been deposited by streams. The rocks of the first group are of Permian age and were formed at a period of time very remote from that in which the rocks of the second group were formed. The younger rocks were probably all formed in the Quaternary period, although there is a possibility that some of them may have been deposited during the Tertiary period. The distribution and structure of the rocks in or near the reservoir site are shown in the geologic map and sections in Plate 1.

The Permian rocks include the Chupadera formation-divided into the Seven Rivers gypsiferous member below and the Carlsbad limestone member above-and younger deposits which according to Darton ${ }^{2}$ belong to the Castile formation. The Seven Rivers member consists of gypsum beds and associated red sand and shale of undetermined thickness, overlain by at least 60 feet of interbedded greenish limy shale and limestone, which in places changes laterally into limestone breccia. West of the Atchison, Topeka \& Santa Fe Railway the breccia becomes a persistent bed. This breccia bed possibly records an old land surface with many sink holes. Resting

2 Darton, N. H., The Guadalupe group: Geol. Soc. America Bull., vol. 37, pp. - (in press). 
on the Seven Rivers gypsiferous member is the Carlsbad limestone member, which in the vicinity of the McMillan Reservoir is only about 40 feet thick. It thickens toward the south, however, and in the southern part of the No. 3 reservoir site attains a thickness of several hundred feet. The formation considered to be the Castile formation consists of sandstone and shale, mostly red, and interbedded layers of gypsum, limestone, anhydrite, and salt.

The Quaternary deposits include, from oldest to youngest, quartzose conglomerate, limestone conglomerate, and alluvium along the Pecos and its tributaries. The quartzose conglomerate consists largely of siliceous pebbles and sand, and the overlying limestone conglomerate consists largely of limestone cobbles and boulders. Both of these conglomerates are cemented by calcium carbonate. The deposits that cap the High Plains to the east are regarded as Pliocene. After they were laid down the valley of Pecos River was excavated, and later the river deposited in its valley the materials that now form the quartzose and limestone conglomerates. These conglomerates are therefore regarded as Pleistocene, although their exact age has not been determined, and it is possible that the older or quartzose conglomerate may be of late Pliocene age. The alluvium is made up of silt, sand, and gravel of Recent age and includes the ancient flood-plain deposits underlying the low terrace and the material deposited in the present river channel, chiefly by the tributary arroyos.

\section{QUATERNARY SYSTEM}

\section{RECENT SERIES}

\section{AILUVIUM}

The youngest deposits in the No. 3 reservoir site have been mapped as alluvium, but this alluvium is not all of exactly the same age, although all of it belongs to the Recent epoch of geologic time. A part of it lies in the immediate channel of Pecos River and its tributaries and is continually shifted and reworked by floods. The larger part of the material, however, consists of silt and gravel that underlie an ancient flood plain of the river no longer overflowed even in great floods. This abandoned flood plain stands as a terrace 15 to 30 feet above the present river channel. In addition to the deposits largely laid down by the river the alluvium also includes some sand, silt, and gravel that have been washed from the adjacent slopes.

The materials composing the terrace or ancient flood plain are different in different places. In the northern part of the reservoir site most of the terrace is underlain by silt and fine sand, except 
where the outcrop of the Carlsbad limestone crosses the river. In this stretch and for a short distance downstream there are a few angular fragments of limestone. In the southern part of the reservoir site, south of the mouth of Rocky Arroyo, the alluvium contains in addition to sand and silt a large amount of gravel, in which wellrounded limestone cobbles and boulders predominate. These cobbles and boulders are similar to those now carried by Rocky Arroyo and were evidently contributed by that stream. Such cobbles and boulders are conspicuously scarce in the alluvium in the northern part of the No. 3 reservoir site.

Near the river channel the arroyos tributary to the Pecos have cut gullies in the terrace corresponding in depth to the incised channel of the river. The floods of these tributaries confined in narrow channels transport a considerable quantity of cobbles and boulders and deposit them in the form of deltas in the river. The coarse gravel is deposited at the mouth of each tributary as a gravel bar, and successively finer material is laid down in the bed of the river below. Consequently, at the mouths of the larger tributaries, especially of Seven Rivers and Rocky Arroyo, the river has been crowded against the east bank, as shown in Plate 1, and runs in small rapids over the gravel bars.

\section{PLEISTOCENE SERIES}

LIMESTONE CONGLOMERATE

In the southern part of the reservoir site (pl. 1) there are two well-defined terraces above the abandoned flood plain mapped as alluvium. Since these terraces were formed they have in many places been eroded and are now represented by hills and ragged spurs. The crenulated topography with remnants of the original flat surfaces of the two terraces is well shown on Plate 1, particularly in the hill just north of Rocky Arroyo. The lower and younger terrace of the two is at an elevation of about 3,275 feet, or 75 to 85 feet above the river, and the older one, which extends to the west beyond the limits of the area mapped, is from 75 to 100 feet higher, or 150 to 185 feet above the river.

These terraces are underlain by very similar limestone conglomerates deposited by Pecos River in the two periods when it flowed at these higher levels. On the geologic map (pl. 1) these two conglomerates have been mapped together as limestone conglomerate, although the conglomerate in the higher terrace is obviously older than that in the lower.

The limestone conglomerate of both terraces consists mostly of well-rounded cobbles and boulders of limestone ranging from about 
an inch to almost 2 feet in diameter. In addition to the limestone pebbles there are some siliceous pebbles, generally not over $1 \frac{1}{2}$ inches in diameter, which seem to have been contributed largely from the underlying quartzose conglomerate. Both the limestone and siliceous pebbles have in most places been cemented by calcium carbonate into a compact conglomerate. The cement is so firm that the conglomerate when struck with the hammer frequently breaks across the pebbles. The conglomerate is so largely composed of limestone pebbles and limy cement that it weathers much like limestone, and the surface of the terraces resemble in many respects near-by limestone surfaces. The slopes of the terraces, however, are largely covered with rounded cobbles that have weathered out of the conglomerate. The limestone cobbles and boulders in the conglomerate have come from a source that lies in a general westerly direction, either from an anciént Rocky Arroyo or from similar streams farther north, and are thus local in origin.

\section{QUARTZOSE CONGLOMERATE}

In the bluffs along Pecos River in the lower part of the reservoir site a quartzose conglomerate is exposed below the limestone conglomerate that has just been described. This conglomerate consists largely of pebbles of chert, jasper, quartz, agate, and quartzite in a matrix of well-cemented sand. As the pebbles are well rounded and rarely exceed $1 \frac{1}{2}$ inches in diameter, they have evidently been transported a long distance. There are also some pebbles and cobbles of limestone, many of which are several inches in diameter and apparently have not been transported as far as the siliceous pebbles. The matrix of this conglomerate is a fairly coarse sand which is held together by a calcareous cement. In this formation there are also lenses of sandstone interbedded with and grading into the typical conglomerate.

It is believed that the quartzose conglomerate represents an ancient channel deposit of Pecos River. On the east side of the Pecos, in the central part of the reservoir site, there is a distinct trench in the underlying Castile formation that has been filled with this conglomerate, and on the near-by Castile outcrop there is a veneer of residual siliceous pebbles.

The quartzose conglomerate is, in most places, so well indurated that it is capable of standing as a vertical face in a bluff. On weathering it produces a sandy soil containing siliceous pebbles, as for example on the east side of Pecos River about half a mile north of the mouth of Rocky Arroyo.

At all places where the lower contact of this conglomerate is exposed it rests on the Castile formation, but on the west side of 
the Pecos it doubtless rests on the Carlsbad limestone member of the Chupadera formation. Although the boundary between the quartzose and limestone conglomerates is indefinite in many outcrops, there are indications of a distinct unconformity between them. At a number of places in the east bluff of the Pecos, south of the mouth of Rocky Arroyo, the quartzose conglomerate is tilted and otherwise deformed, whereas nowhere within the area examined was the limestone conglomerate found to be deformed. The existing remnants of the two terraces underlain by the limestone conglomerate are smooth and have the gentle slopes characteristic of terraces. These slopes are accordant with each other, sloping from north to south, parallel to the course of the river, and from each side toward the river, parallel to the tributary streams. The limestone conglomerate thus appears to be wholly undeformed, whereas the underlying quartzose conglomerate has been broken and tilted. The deformation of the quartzose conglomerate appears to be due to fracture and slumping caused by the removal of soluble material from the underlying Castile formation (p. 11).

On the south side of the river at the dam site both conglomerates are exposed; on the north side the quartzose conglomerate is probably present but is concealed by a cover of limestone cobbles that have weathered out of the limestone conglomerate. In the terraces just north of Rocky Arroyo, on the south side of the river, there is doubtless a considerable deposit of the quartzose conglomerate, but in general it is covered with cobbles from the overlying limestone conglomerate.

\section{CARBONIFEROUS SYSTEM}

\section{PERMIAN SERIES}

The Permian rocks in this area have not been traced into the Guadalupe group of Texas, which is divided into the Delaware Mountain formation below and the Capitan limestone above, formations which were originally defined by Richardson ${ }^{3}$ and later studied by Girty. ${ }^{4}$ Darton, ${ }^{5}$ however, has recently traced the Permian rocks of the Guadalupe Mountains northward along the west side of the Pecos Valley, and according to him the Carlsbad limestone of this report forms the upper part of the Capitan limestone that lies at the top of El Capitan, at the south end of the Guadalupe Mountains.

\footnotetext{
${ }^{3}$ Richardson, G. B., Report of a reconnaissance in trans-Pecos Texas north of the Texas \& Pacific R. R.; Texas Univ. Bull. 29, 1909 ; The stratigraphy of the Upper Carboniferous in west Texas and southeastern New Mexico: Am. Jour. Sci., 4th ser., vol. 29, pp. 325-337, 1910.

\Girty, G. H., The Guadalupian fauna: U. S. Geol. Survey Prof. Paper 58, 1908.

5 Darton, N. H., The Guadalupe group: Geol. Soc. America Bull., vol. 37, pp. (in press).
} 
All the Permian rocks below the Castile formation described in this report are at present included by Darton in the upper part of the Chupadera formation. ${ }^{6}$

\section{CASTILE FORMATION}

According to the recent work of Darton, ${ }^{7}$ the rocks mapped as Castile formation in Plate 1 apparently represent the lower part of the northern extension of the Castile gypsum ${ }^{8}$ of Texas. The lower part of this formation is exposed on the east side of Pecos River in the No. 3 reservoir site, and thence the formation extends eastward and northeastward for a considerable distance. As seen in numerous outcrops it consists largely of soft sandstone and shale, mostly red but including some beds that have a greenish tint. There are also presistent beds of limestone and gypsum. A test hole drilled in 1905 on the Allen Hurd land (fig. 1) encountered gypsum at a depth of 6 feet and continued in that material interbedded with small amounts of shale to a depth of 65 feet. Locally the gypsum beds in the Castile formation are sufficiently thick to be workable, and along the railroad in the NE. $1 / 4$ sec. 18, T. 20 S., R. 27 E., there is a cement mill which uses gypsum taken from an open pit about half a mile east of the mill. It is reported that wells in the Artesia oil field encounter beds of salt and anhydrite in the Castile formation. At the outcrops the soluble materials, such as salt, gypsum, and anhydrite, have largely been dissolved out of the formation. Within the No. 3 reservoir site three outcrops of gypsum have been found (fig. 1 and pp. 25-26). Solution of soluble rocks with resulting slumping and tilting of the overlying strata is prevalent in this part of New Mexico and has recently been described by Lee. ${ }^{\circ}$ As a result of this process much of the Castile formation that crops out within the reservoir site has been thus deformed. The spectacular results of this process are particularly noticeable in the limestone beds, which have been broken and contorted. Individual blocks of limestone ranging in size from a few feet to several hundred feet have been tilted in all directions and limestone breccia is common.

In the southern part of No. 3 reservoir site the river flows very close to the boundary between the Castile formation and the underlying Carlsbad limestone, but the contact is largely concealed by the

\footnotetext{
6 Darton, N. H., Geologic structure of parts of New Mexico : U. S. Geol. Survey Eull. 726, pp. 181-182, 1922.

${ }^{7}$ Darton, N. H., Geol. Soc. America Bull., vol. 37, p. - (in press).

${ }^{8}$ Richardson, G. B., U. S. Geol. Survey Geol. Atlas, Van Horn folio (No. 194), p. 6, 1914.

Lee, W. T., Erosion by solution and fill: U. S. Geol. Survey Bull. 760, pp. 107121, 1925.
} 
two overlying conglomerates and the alluvium. As shown on the geologic map (pl. 1), the Castile formation crops out in only one place west of the river.

\section{CHUPADERA FORMATION}

The rocks here assigned to the Chupadera formation are divided into two members, for the upper of which the name Carlsbad limestone member is adopted and for the lower the name Seven Rivers gypsiferous member. The Chupadera is overlain by the Castile formation and is the oldest formation that crops out in this area.

Carlsbad limestone member.-The limestone here designated the Carlsbad limestone member of the Chupadera formation has for some time been locally called the Carlsbad limestone, because of its outcrops west and northwest of Carlsbad. It is doubtless in part at least the equivalent of the Big lime of Lee. ${ }^{10}$ It crops out south and west of the reservoir site, crosses Pecos River at the constriction of the valley below the mouth of Seven Rivers, and forms the upper part of the bluff on the southeast side of Pecos River above the constriction. Where the limestone crosses Pecos River it forms ledges in the bed of the stream.

Northwest of Carlsbad, in sec. 34, T. 21 S., R. 26 E., where a well is now being drilled for oil, the Carlsbad limestone is at least 800 feet thick, and southwestward toward the New Mexico-Texas line it apparently attains a still greater thickness. Inspection of the outcrops in the southern part of the reservoir site indicated that the limestone is thinner there than at the localities mentioned, but on the west side of the river it is still several hundred feet thick. As the beds are traced northward they are found to thin rapidly. As measured in the bluff south of Pecos River between the mouth of Seven Rivers and the railroad the limestone did not exceed 100 feet in thickness. The limestone that caps the bluff at the south end of the McMillan Reservoir was found to be the same bed by tracing it from the outcrops previously deseribed, but here it is only about 40 feet thick. The Carlsbad limestone, though essentially a limestone unit, contains lenses of sandstone, and in some places west of the areas mapped lenses of red beds (sand or shale) were noted along the outcrop.

In the vicinity of the reservoir site the Carlsbad limestone is a relatively thin-bedded rock in which individual beds usually do not exceed 2 feet in thickness. The rock itself is dense, and the joints are clean fractures but little opened by weathering. It resists erosion and generally forms hills and ridges. The valley of Pecos River where it crosses the outcrop is narrow and marked by steep bluffs, 
a measure of the resistance of the rock to the lateral erosion of the river.

However, the limestone yields to the solvent action of water at the surface and underground. In the general region lange springs and extensive deposits of travertine testify to its cavernous condition, and large springs issue from crevices in it along the river in the No. 3 reservior site. To what extent the work of solution has proceeded in the vicinity of the reservoir site is not wholly manifest from an inspection of the outcrops of the Carlsbad limestone but must be inferred on hydrologic grounds, as set forth on pages 18-28.

The exposures of the limestone show small folds (anticlines and synclines), most of which do not exceed a few hundred feet in length. The dips in some of these folds are as much as $45^{\circ}$, but these dips do not conform to the regional structure of the Carlsbad limestone. It seems likely, therefore, that these minor crumplings have resulted from the solution of underlying material, such as salt, anhydrite, gypsum, or limestone, and the consequent yielding of the Carlsbad limestone to slumping on the removal of its support.

Seven Rivers gypsiferous member.-In the northern part of the No. 3 reservoir site and in the vicinity of the McMillan Reservoir beds that lie stratigraphically below the Carlsbad limestone member are well exposed. Near the McMillan Dam, just below an outcrop of the Carlsbad limestone, there is an excellent exposure of about 50 feet of interbedded greenish limy shale and compact limestone. These beds have been considerably deformed in small folds and minute faults that are doubtless due to the removal of underlying soluble material. In the south spillway, just east of the railroad and about half a mile west of the McMillan Dam, the same beds are exposed, but there they have been deformed to a much greater degree than at the McMillan Dam. In the bluff along the southeast edge of the McMillan Reservoir 100 feet or more of gypsiferous beds are exposed. Numerous small sinks in the reservoir suggest that these gypsum beds extend northward under the reservoir. These beds of gypsum and associated red sand and shale are believed to be stratigraphically below a persistent breccia bed which is the stratigraphic equivalent of the interbedded greenish limy shale and limestone that crop out in the vicinity of the McMillan Dam. The gypsum and the overlying deformed and brecciated limy strata constitute the Seven Rivers gypsiferous member of the Chupadera formation, as defined in this report. The beds are given this name because they are well exposed in the bluffs south of Seven Rivers, notably in the bluff that lies in secs. 17 and 18, T. 20 S., R. 26 E. Beds of gypsum also crop out north of this bluff, where the surface is more flat, and here sink holes are plenti- 
ful. West of the railroad, in secs. 3 and 10, T. 20 S., R. 26 E., along the south side of the north spillway of the McMillan Reservoir, beds of the Seven Rivers member are at the surface, and there are at least four large sink holes. The one shown on the map (pl. 1) has been filled by alluvium. All these sink holes have resulted from the solution of gypsum or other soluble material by the ground water. The dissolving of the material produced large caverns, the roofs of which have in some places caved in.

Some beds in the upper part of this member consist of fragments of limestone cemented in a matrix of limy material. The limestone fragments vary in shape from angular fragments to rounded masses. Most of the material is a true breccia, but some is more nearly a conglomerate. The proportion of breccia to normal material of the Seven.Rivers beds increases from the McMillan Dam toward the southwest, and in the bluff south of the Pecos and west of the railroad there is a continuous and persistent bed of breccia immediately below the Carlsbad limestone. This bed extends from the outcrop of the Carlsbad limestone to the alluvium bordering the river and has a maximum observed thickness of 60 feet.

Generally the breccia beds vary in thickness along the outcrop and in places end abruptly against normal limestone. At the Avalon Dam a bed of breccia lies below the normal limestone on which the spillway gates are built. Partly dislodged fragments of the limestone lie in the breccia adjacent to the cavities from which they have been dislodged. It is evident that here the breccia was formed after the overlying limestone had been laid down and consolidated. The breccia appears to have been deposited in a cave that once existed at this place and had the limestone for its roof. The fragments of the breccia consist largely of masses of this roof detached by caving and more or less transported and cemented into a hard rock by the waters circulating in the cave. This particular bed and doubtless many others furnish examples of the process of solution and fill described by Lee. ${ }^{11}$

The persistent breccia at the top of the Seven Rivers gypsiferous member south of Pecos River and at the south spillway of the McMillan Reservoir may, however, represent an ancient sink-hole country of Permian time. Here solution and fill may have taken place as they do now, and the breccia may have been formed and cemented before. the Carlsbad limestone was laid down. Locally the Carlsbad limestone does not seem to have been so much deformed as the persistentunderlying breccia bed, and this fact adds weight to the hypothesis. that part of the solution and fill which produced the breccia took place in Permian time and therefore records an unconformity within

${ }^{11}$ Lee, W. T., Erosion by solution and fill : U. S. Geol. Survey Bull. 760, pp. 107-121, 1925. 
the Permian. According to Darton, ${ }^{12}$ unconformities in the Permian are found at other places in southern New Mexico and in Texas.

\section{STRUCTURE}

No. 3 reservoir site occupies the nose of a southeastward-plunging syncline. This structure is not entirely defined within the area covered by the geologic map ( $\mathrm{pl} .1$ ), but an examination of the rocks in the adjoining area shows that the Carlsbad limestone member reflects a structure of this type. In the northern part of the area shown on the geologic map the Carlsbad limestone dips southeast. West of the Pecos, just beyond the area, this limestone dips east. South of the reservoir site the same beds generally dip to the north, although in places there are notable changes in dip. East of the Pecos, in the latitude of the dam site, the rocks dip toward the southwest. This distribution of dip and strike defines a structural basin which resembles in form a basin of deformation, but may have been produced by solution of underlying soluble material and consequent settling of the overlying beds. In this basin is the Castile formation, most of which, within the reservoir site, has been covered by the quartzose conglomerate, the limestone conglomerate, and the alluvium. That settlement has played a large part in the formation of this basin seems the more likely because of the wide departures from the prevailing dip shown in all parts of the structural basin by outcrops of the Carlsbad limestone.

The Castile formation, in proximity to the river, has been greatly deformed, presumably because the soluble material has been dissolved out and the beds above have caved. At a distance of a mile east of the river and thence eastward this deformation of the Castile strata is not so evident, and it seems likely, therefore, that the greater disturbance of the beds immediately adjacent to the Pecos is directly related to a more active ground-water circulation near the river. On the other hand, the drainage tributary to Pecos River originating from rainfall on the adjacent upland east and northeast of the river is feeble. Whether it reaches Pecos River as surface or as underground streams it is incapable of large or rapid erosion. As this condition doubtless existed in the past underground solution has not been so active a process in the Castile beds at any great distance from the major drainage line. Pecos River, however, is a competent agent to dissolve and carry off large quantities of material. It has probably for a long time flowed in or near its present channel, partly at the surface and partly as an underground stream. Certainly during the long period required for the formation of the terraces underlain by the limestone conglomerate the river has in this area been confined to a relatively narrow zone on each side of

12 Darton, N. H., oral communication.

$94680^{\circ}-27-2$ 
its present channel. The greatest amount of solution should be expected near the river, and at a distance the Castile formation should contain more nearly its original quantity of salt, gypsum, and anhydrite.

The length of time over which the process of solution has continued is uncertain, but it is important to determine to what extent the process is complete in the vicinity of the reservoir site. It is evident that some soluble material has been removed from the Castile formation since the quartzose conglomerate was deposited, as the conglomerate.has been appreciably deformed, though not nearly as much as the underlying Castile strata. The limestone conglomerate, on the other hand, was at no place observed to have been affected by this process. These facts suggest that most of the soluble material in the Castile formation may have been dissolved out before the limestone conglomerate was deposited. A structural unconformity therefore clearly exists between the deformed quartzose conglomerate and the overlying undeformed limestone conglomerate. However, three outcrops of gypsum are known along the river bank, and gypsum was also found in the test drilling in the Hurd pasture and in hole No. 3 drilled in 1925 (p. 35). As a result of the early solution of material from the Castile formation caverns and sinks were developed, but presumably these have largely been filled by caving of the sand, shale, and limestone of the Castile formation and by the accumulation of the later conglomerates. The Carlsbad limestone is, of course, also soluble.

\section{INDICATIONS OF LEAKAGE OR WATER-TIGHTNESS}

\section{GENERAT PRINCIPIES}

In order to set forth clearly the aims and purposes of the present investigation and to show the grounds for the conclusions that have been reached, the general principles pertaining to the leakage of reservoirs are set forth below, followed by a detailed description of localities and a critical analysis of the problem of water-tightness.

Observations of two kinds bear on the question whether a proposed reservoir will leak or hold water-(1)' observations as to the composition, texture, and structure of the rocks that form the surface of the reservoir site or lie close to the surface; (2) observations as to the occurrence and behavior of the ground water below the reservoir site and in its vicinity.

Rocks that contain only small pores or joints usually form satisfactory walls and bottoms for reservoirs. The moderate amounts of water which they allow to percolate out of the reservoir do not seriously deplete the available supply. Moreover, such small openings largely become clogged or silted up in the course of time. The 
rocks that are most likely to allow serious leakage are those which may have large openings, such as limestone, gypsum, extrusive basalt, and coarse unconsolidated gravel.

Wherever a dam is built across a stream the water level in the resulting reservoir is raised above the ground-water level or water table. Unless the rocks that contain the reservoir are entirely impermeable, a hydraulic gradient is established between the water in the reservoir and the ground water, and some loss from the reservoir occurs. Under what may be regarded as normal conditions before a dam is built, the water table slopes gently toward the stream from both sides. Under these conditions the water surface in the reservoir will stand highest above the water table at the lower end of the reservoir, at both sides of the dam, and will approach the water table at the head of the reservoir. Hence the most critical part of a reservoir with respect to leakage is usually at the lower end. If a reservoir is located along a drainage line or other depression that lies above the water table the danger of leakage in all parts of the reservoir is obviously greater.

The safest reservoirs with respect to leakage are those which are in relatively tight rocks with only small pores and joints and which lie along main drainage lines toward which the water table slopes. These also constitute the most common type of reservoirs. Gravel or other permeable alluvium may occur at the dam site, resting on a floor of hard, dense rock and confined between walls of the same rock. At such a dam site leakage can be prevented by well-known engineering methods. Conditions of this type are the most familiar to hydraulic engineers; they are the most easily determined and evaluated and the most easily controlled. Where there is danger of leakage through cavernous rocks in the abutments or in other parts of the reservoir, however, the problem is much more complex, and remedial measures are difficult or wholly impracticable.

Tight rock in the abutments of the dam is of great importance, because in this part of the reservoir the impounded water will necessarily stand high above the natural water table. Thus it is essential to determine to what extent the anticipated hydraulic head in the abutments will cause flow through the kind of rock of which they are composed. The amount of this flow must be estimated, and its effect on the stability of the abutments and the foundation of the dam must be considered.

In the rest of the reservoir site the height of the water table and the character of the rock are very important. If in any given direction the water table rises to the proposed level of the water surface in the reservoir, there is no danger of loss by leakage in that direction; on the contrary, the effective capacity of the reservoir may be increased by underground storage. Thus the water level may be 
raised to the height of the lowest ground-water divide on all sides of the reservoir. This favorable relation to the water table exists in most successful reservoirs, except, of course, at the lower end. Observations must therefore be directed to determine the position of the water table-whether it slopes toward the reservoir from both sides and downstream or whether it lies so low or is so flat that it will not form a barrier to the water that may percolate outward through the sides of the reservoir.

In general, rocks that have small openings, such as granite, clay, shale, and also most beds of sand and sandstone, have a low permeability, so that the water table in them has considerable slope and conforms in general to the slope of the land surface. Under such conditions reservoirs will generally be water-tight or have only moderate leakage to some point in the same drainage basin below the dam:

On the other hand, rocks that have large openings, either original or secondary, such as cavernous limestone, gypsum, rock salt, extrusive basalt, and coarse unconsolidated gravel, are likely to have a flat water table which may not rise much above the stream level and may even lie below the stream level or slope away from the streams. If a reservoir is built where such conditions exist, the water may readily escape through the large openings in the rocks, may flow long distances underground, and may even make its appearance in a different drainage basin.

Some of the worst failures due to leakage have occurred where the water table stood far below the reservoir site-for example, the Jerome Reservoir, in the basaltic rocks of Idaho, and the Hondo Reservoir, in the gypsiferous rocks of New Mexico. ${ }^{13}$ In the vicinity of the Hondo Reservoir the channel of Hondo River is, according to available well data, fully 200 feet above the water table.

\section{DETAILED DESCRIPTION OF THE NO. 3 RESERVOIR SITE}

General relations.-Pecos River forms the main drainage line of eastern New Mexico and its valley lies far below all the adjacent country. Numerous wells on the highland east of the Pecos obtain water from rocks at elevations considerably higher than the valley. Hence, although the rocks of the region dip gently to the east and southeast, they apparently do not carry water from the valley of Pecos River eastward into another drainage basin. It is practically certain that a reservoir located in the position of the No. 3 site would not cause leakage to any other drainage basin.

However, the rocks of the region include much limestone, gypsum, anhydrite, and salt, in which large openings due to the solvent

\footnotetext{
${ }^{13}$ Davis, A. P., Irrigation works constructed by the United States Government, pp. 231-233, 1917.
} 
action of circulating ground water may occur. The openings will permit rapid flow on low gradients, and therefore a flat water table may be expected, with the danger of leakage to some point farther downstream. These unfavorable general conditions characteristic of the region are, however, not conclusive with respect to the No. 3 site, for although the McMillan Reservoir suffers excessive lossee the Avalon Reservoir has no notable leakage. The ground-water conditions, governed by the detailed structure and distribution of the rocks within and adjacent to the No. 3 site, are the critical factors in regard to the proposed reservoir.

As shown on the geologic map (pl. 1), a large part of the No. 3 site is occupied by the quartzose conglomerate and the limestone conglomerate. The indurated parts of these formations, especially of the quartzose conglomerate, may contain some large joints, and the slightly consolidated parts may grade into permeable gravel; but, on the whole, the rate of movement of water through these rocks would probably be slow even under considerable head. In the abutments of the dam there would probably be some leakage through these conglomerates, but the relatively small quantities of water that would be lost here would be recovered in the Avalon Reservoir. Therefore, in so far as these formations occur in considerable thickness in the reservoir site, they are favorable to essential water-tightness.

The alluvium, which underlies the lowest terrace, is a silty deposit with interbedded lenses of gravel. It will retard leakage but will not prevent the formation of sink holes if it is underlain by either limestone or gypsum that contains large crevices.

The danger of serious leakage therefore lies essentially in the Carlsbad limestone, which crosses the river in the spring-fed stretch, and in the gypsum, red beds, and breccia that lie both above and below this limestone-the Castile formation above and the Seven. Rivers gypsiferous member of the Chupadera formation below. The characteristics of these rocks and their relation to the movement of water are considered in detail in the following paragraphs, in which also the essential facts that bear on the position and form of the water table are set forth.

Seven Rivers area.-A number of deep pool springs occur in the channel- of Seven Rivers a short distance upstream from the reservoir site, at an elevation of about 3,275 feet. In July, 1925, the water from these springs flowed down Seven Rivers to the highway crossing, where it sank into the channel gravel. No ground water appeared at the surface between the highway crossing and the mouth of Seven Rivers. South of Seven Rivers and west of the reservoir site (apparently in the NW. 1/4 sec. 17) is Nelson's Spring, which in past years has irrigated considerable land but which in July, 1925, was dry, with the water level at least 8 feet below the sur- 
face. North and west of this dry spring there are flowing artesian wells; south and southwest of it gypsum or gypseous soil are at the surface, and there are numerous sink holes. No information could be obtained in regard to ground water in the area lying south of this dry spring and west of the large spring (the largest of the group known as the Major Johnson Springs) on Pecos River in the

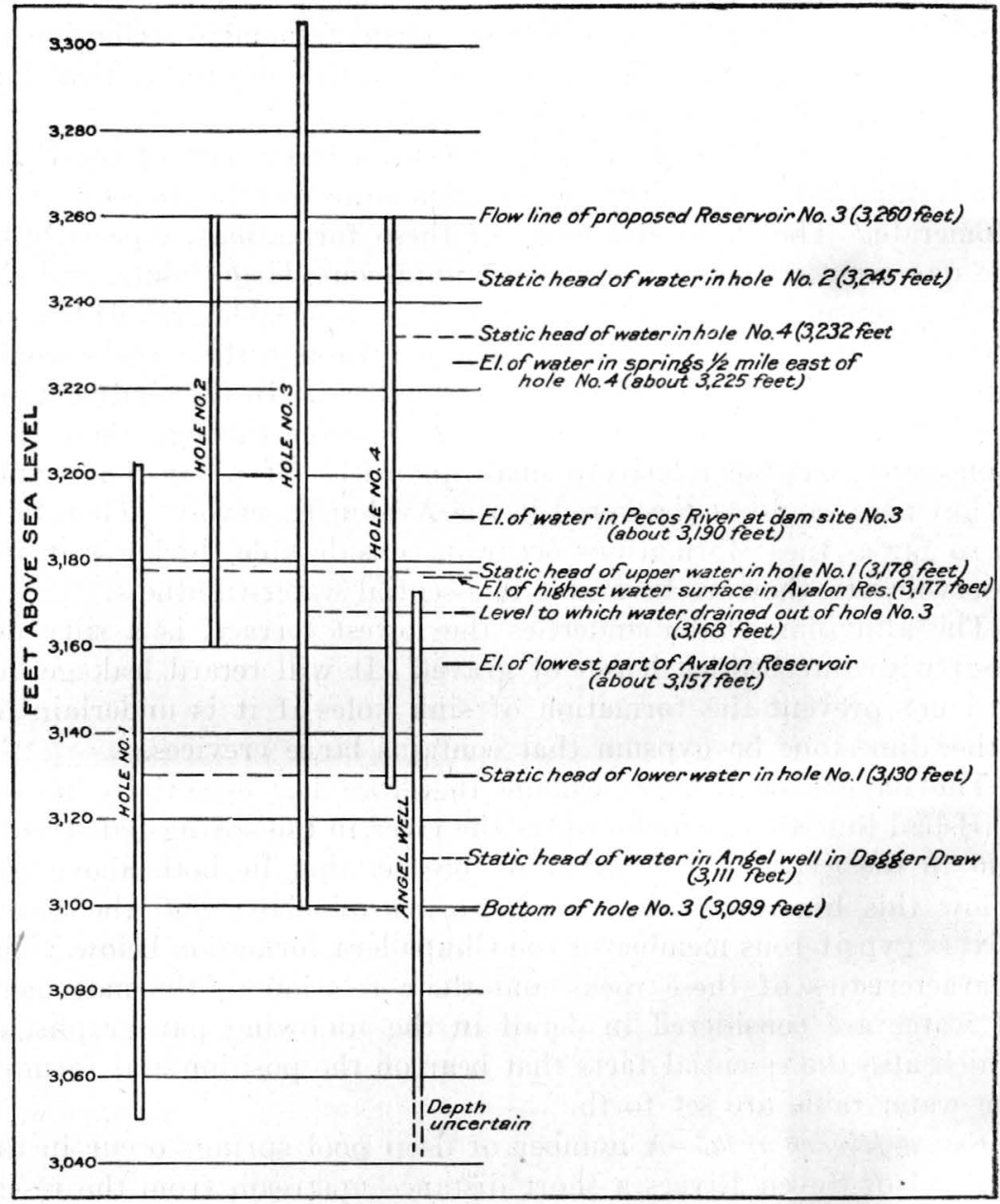

FIGURE 2.-Water levels in test holes drilled in 1925 , in relation to other water levels in or near the No. 3 reservoir site of the Carlsbad irrigation project, New Mexico

NW. $1 / 4$ sec. 21 . Unless very abnormal ground-water conditions exist west of Pecos River the water that seeps into the ground in this locality should go into ground storage and should not be lost to the reservoir. Test hole No. 4 was drilled in 1925 at about the 3,260foot flow line, in the NE. $1 / 4$ sec. 20 , about half a mile west of the large spring on the Major Johnson place. (See pp. 37-39, pl. 1, and 
figs. 1 and 2.) This hole was drilled to determine whether the ground water under this area drains toward Pecos River, as it should, or drops abnormally toward the south. The hole was drilled to a depth of 132 feet and encountered much water below a depth of 28 feet. The static head of the water in the hole is 28 feet below the surface, or at an elevation of 3,232 feet, which is slightly above the water level of the Major Johnson Spring and indicates a normal ground-water leyel.

McMillan spillway area.-The north spillway of the McMillan Reservoir enters the reservoir site from the north and discharges into Seven Rivers about at the north line of sec. 16. (Fig. 1.) No springs were found in this spillway. It passes over the Seven Rivers gypsiferous member. On the east side of the spillway are several large sink holes in gypseous red beds, which probably mark the course of an ancient underground channel of Pecos River. The general surface at this locality is a little above the 3,260-foot flow line, but the sink holes extend down below that level. This area is obviously not water-tight, but as it lies at the upper end of the reservoir there is apparently no direction in which the water could escape without returning to the reservoir farther downstream.

McMillan Reservoir area.-The history of the McMillan Reservoir has been briefly sketched on page 4 . The area of the reservoir is underlain by the red beds and gypsum of the Seven Rivers gypsiferous member, covered over most of the floor by alluvium and recently accumulated silt. The spillways of the McMillan Reservoir are at an elevation of about 3,286 feet. The bottom of the reservoir has been raised by silting, so that at the dam it lies about 20 feet below the spillways and in most parts of the reservoir only 10 feet below this level.

Yet the waves from this shallow body of water, which exists for only part of the year, have eroded up to the flow line the soil that once covered the thick beds of gypsum that form the southeast wall of the reservoir. In the massive beds of gypsum exposed by this wave work there are large solution channels that, when the reservoir is full, take in water in large quantities. The silt floor of the reservoir at some distance from the shore contains numerous and conspicuous sink holes, which obviously drain downward into crevices in the underlying rock. The leakage through the channels on the shore and the sink holes is large and in 1904 was estimated at about 10,500 acre-feet a month, or a continuous flow of about 175 second-feet. Since that date many measurements and estimates of leakage have been made, and the highest estimated rate when the reservoir is full is more than 300 second-feet.

So large a leakage appears to indicate that prior to the construction of the reservoir large solution channels had been developed 
that at one time or another carried all or part of Pecos River underground from the southeast side of the present reservoir to the vicinity of the Major Johnson Springs.

In 1909 an embankment was constructed to isolate some of the largest sink holes, but it has not been very effective. Owing to the caving of the underlying material the embankment itself in some places has sunk, and large leakage below it is now taking place. The originally inconspicuous channels north of the embankment appear to be carrying progressively larger quantities of water.

The serious leakage from the McMillan Reservoir takes place through solution passages in the Seven Rivers gypsiferous member, and the water returns to Pecos River within No. 3 site, as described more at length in the next section. These rocks crop out only in the northern and shallow part of No. 3 Reservoir and pass southward under the Carlsbad limestone at considerable depth, and it is entirely possible that at that depth they are tight and free from cavities. Thus, the fact that leakage occurs from the McMillan Reservoir does not necessarily indicate that leakage would occur from No. 3 Reservoir, but it seems likely that the opening of solution passages in the Seven Rivers gypsiferous member furnishes an analogy from which a similar process in the gypsum of the Castile formation at the south end of the No. 3 reservoir site may be predicted.

Stretch between McMitlan Reservoir and mouth of Seven Rivers.From the McMillan Dam to the mouth of Seven Rivers, a distance of about 3 miles, the limestone breccia of the Seven Rivers member crops out at many places in the channel and banks of Pecos River, chiefly on the southeast side. The breccia doubtless rests on red beds and gypsum of the Seven Rivers member, but no red beds or gypsum are exposed along the river. The breccia is overlain by the Carlsbad limestone. In the vicinity of the railroad the contact between breccia and overlying limestone is well above the flow line of the proposed reservoir, but downstream it gradually descends, until below the mouth of Seven Rivers the limestone appears in the river channel. The outcrops of breccia between the railroad and the mouth of Seven Rivers appear firm and tight and show no openings that would be likely to cause leakage. There are no springs or seeps in this stretch of the river, but salt grass occurs on the banks and luxuriant mesquite trees on the low alluvial terrace, and the presence of these plants suggests that a water table from which they obtain their water supply exists at no great depth. Careful inspection revealed no indication that river water has escaped or is escaping into the rock or into the alluvium that underlies the terrace and mantles the rock in most places. Along the south spillway of the McMillan Reservoir there is a large fresh artificial ex- 
posure of the breccia. Here it contains many crevices and some rather large solution channels that could doubtless carry much water.

Spring area.-Numerous springs issue along the banks and in the bed of Pecos River for a distance of about $1 \frac{1}{2}$ miles in a stretch beginning in sec. 16 , a short distance downstream from the mouth of Seven Rivers, and extending about to sec. 27. The largest springs arise in the bed of the river, near the west bank, on the Major Johnson place, in the NW. $1 / 4$ sec. 21. Smaller springs occur along the west bank for some distance, and many springs, some of them large, occur on the east bank. A minimum discharge of about 40 secondfeet for the entire group has been estimated from numerous measurements of the flow of the river taken simultaneously above and below the springs. Most of the water doubtless issues from the large springs in the bed of the river, but even in a period of nearly minimum discharge in July, 1925, some of the other springs yielded close to 1 second-foot each.

The extensive and careful investigation of these springs by Messrs. Foster and Yates shows conclusively that they are supplied chiefly by the water that leaks out of the McMillan Reservoir. When the water accumulates in the reservoir the discharge of the springs increases greatly, the increase becoming noticeable about five days after the reservoir begins to fill. Measurements made in 1921 when the reservoir was full showed a discharge from the springs of 272 second-feet. As soon as the reservoir is empty the discharge begins to decrease, and, according to rough estimates by Bonstedt and Debler, it declines in the course of about a month to the minimum of approximately 40 second-feet and thereafter continues at a fairly uniform rate until leakage from the McMillan Reservoir again augments the flow. This lag indicates that the water flows through a considerable area of cavernous rock in which it is temporarily stored.

The following table showing the quantities of water that have been lost by leakage and that have been recovered through the springs has been taken from the report by Bonstedt and Debler:

Leakage from McMiblan Reservoir compared with discharges of the entire group of the Major Johnson Springs, in acre-feet

\begin{tabular}{|c|c|c|c|}
\hline & \begin{tabular}{|} 
Average, \\
$1912-1915$
\end{tabular} & 1918 & Average, \\
\hline $\begin{array}{l}\text { Loss from McMillan Reservoir } \\
\text { Discharge of springs }\end{array}$ & $\begin{array}{l}140,000 \\
100,000\end{array}$ & $\begin{array}{l}72,690 \\
74,000\end{array}$ & $\begin{array}{l}134,500 \\
164,400\end{array}$ \\
\hline
\end{tabular}

Bonstedt and Debler assumed that 40 second-feet, or 29,000 acrefeet a year, of the spring discharge is derived from other sources than 
the leakage out of the McMillan Reservoir, and estimated that 70 per cent of the leakage reappears in the springs and 30 per cent does not reappear anywhere above the Avalon Dam. However, Foster and Yates, on the basis of recent careful work, are of the opinion that substantially all the leakage from the McMillan Reservoir reappears in the springs. Obviously the discharge of this leakage into the No. 3 reservoir site is a favorable condition.

The spring area coincides almost exactly with the belt in which the Carlsbad limestone crops out in the channel and banks of Pecos River. The water from the reservoir, however, is discharged into the gypsum beds, and it probably flows through openings in these beds or in the breccia nearly to the springs. Though creviced and permeable where the springs rise through it, the Carlsbad limestone or thin shale beds in the base of the Castile formation apparently serve as a barrier, directing the water back to the river in the spring area instead of leading it to the area of low water table to the south.

The springs issue at elevations of about 3,220 to 3,230 feet, or 30 to 40 feet below the 3,260 -foot flow line. When the proposed reservoir is full the back pressure on these springs will fill the underground channels that lead to them and will back up the water in these channels nearly to the McMillan Reservoir. Unless the system of underground channels that conveys the water from the McMillan Reservoir to the springs is essentially tight under the head produced by a water level of 3,260 feet and constitutes a closed system of pipes, the water will escape underground in some unknown direction, the flow of the springs will be reversed, and the openings will form effective conduits for serious leakage. These underground channels presumably lie on a northeast line between the springs and the southeast border of the McMillan Reservoir. As the area to the south of this line is underlain chiefly by soluble rocks consisting largely of gypsum and salt, there is evidently danger that similar channels exist through which the water might escape unless the water table in this area were up to about the level of the proposed flow line. If water were lost into this area there is no assurance that it would return to the river above the diversion at the Avalon Dam, for it might continue southward through gypsiferous beds or limestone to the vicinity of Carlsbad. The possibility of escape from the system of underground channels leading from the McMillan Reservoir to the Major Johnson Springs constitutes one of the most serious dangers of leakage from the proposed reservoir. If the water did not return above the Avalon Dam, this leakage might even render the proposed reservoir worthless.

The somewhat indefinite information in regard to the wells sunk at the Oriental Cement Works, in sec. 18, T. 20 S., R. 27 E., is not 
encouraging. This information was furnished from memory by Mr. F. E. Hubert, manager of the works, and is as follows: The first well, situated west of the railroad, was 3 inches in diameter and 360 feet deep, had a water level about 320 feet below the surface, and when pumped with a windmill yielded an unfailing supply of water of bad quality. The second well, drilled in 1912 at the boiler house, was 8 inches in diameter and 600 feet deep. It struck gas but no water. The third well, drilled in 1913 and now in use, is a short distance east of the mill, and the elevation of the top of the wooden block at this well was determined by instrumental leveling to be 3,308 feet. The well is 3 inches in diameter and 185 feet deep, contains 40 to 100 feet of water, and has never been dry.

Test hole No. 3, drilled in 1925 in the NE. $1 / 4$ sec. 26, T. 20 S., R. 26 E., at an elevation of 3,305 feet, was carried to a depth of 206 feet without finding water. Water that was poured into the hole drained out to a depth of at least 137 feet, or to an elevation of 3,168 feet, which is about 90 feet below the high-flow line of the proposed reservoir, 55 feet below the river level due west of the test hole, and 20 feet below the river level at the dam site. (See pp. $35-37$, pl. 1, and figs. 1 and 2.)

Reservoir site below spring area.-The lower half of the reservoir site, below the springs, is largely underlain by rather thick deposits of the quartzose and limestone conglomerates and the Recent alluvium. On the west side these formations rest mainly on the Carlsbad limestone; on the east side they rest on the Castile formation, which in turn rests on the limestone. Beds of the Castile formation crop out along the river, below the conglomerate beds, as shown on the geologic map. The quartzose conglomerate and underlying breccia of the Castile formation are exposed in several localities on the east side of the river in bold and rugged outcrops that attract attention from a distance. They form a confused mass of rock with cavities due to differential weathering. Careful examination, however, revealed no openings that are taking in river water or that appear to be sufficiently continuous to act as conduits for water.

The normal sequence of the Castile formation includes thick beds of gypsum, which are obviously unfavorable to water-tightness, but not much gypsum is visible within the reservoir site. In this respect the No. 3 site compares favorably with the McMillan Reservoir, where extensive outcrops of gypsum occur below the flow line. The scarcity of gypsum at the surface at the No. 3 site is believed to be due partly to its removal by solution in past ages and partly to its being covered by alluvium and débris, in contrast with the hard conglomerate, limestone, and breccia, which crop out in bluffs. A small outcrop of gypsum was observed in a gully near the middle of 
sec. 35, T. 20 S., R. 26 E., and small outcrops are reported by Richardson near the line between secs. 35 and 26, in the same township, and in a low bluff in the W. $1 / 2$ NW. $1 / 4$ sec. 6, T. 21 S., R. 26 E.

In order to obtain information on the occurrence of gypsum beneath this part of the reservoir site 11 holes were drilled with a core drill in 1905 in what is known as Hurd's pasture, in or near the NE. $1 / 4$ sec. 27 , T. 20 S., R. 26 E. These holes ranged in depth from 19 to 96 feet. They encountered a great variety of materials, including much sand, gravel, and clay, and the sections of the different holes were very dissimilar. The largest amount of gypsum was found in hole No. 7, drilled on the 3,240-foot contour about onethird of a mile from the river, in the NE. 1/4 NE. 1/4 sec. 27. This hole was carried to a depth of 96 feet and showed 59 feet of gypsum interbedded with shale. In test hole No. 3, drilled in 1925 about 1 mile farther east, much gypsum was also encountered (p. 35).

Condensed log of test hole No. 7 drilled in Hurd's pasture in 1905

\begin{tabular}{|c|c|c|}
\hline & $\begin{array}{l}\text { Thick- } \\
\text { ness }\end{array}$ & Depth \\
\hline Silt. & Feet & Feet \\
\hline Brown clay.-................ & $\mathbf{4}$ & \\
\hline $\begin{array}{l}\text { Soft gypsum rock } \\
\text { Gypsum }\end{array}$ & $\begin{array}{r}1 \\
19\end{array}$ & $\begin{array}{r}7 \\
26\end{array}$ \\
\hline Red clay shale containing smail veins of gypsum & 5 & 31 \\
\hline Red sandy shale & 2 & \\
\hline $\begin{array}{l}\text { Gypsum } \\
\text { Gypsum mixed with shale }\end{array}$ & $\begin{array}{r}7 \\
25\end{array}$ & $\begin{array}{l}40 \\
65\end{array}$ \\
\hline Sandy shale; "very little water returns" - & 22 & 87 \\
\hline 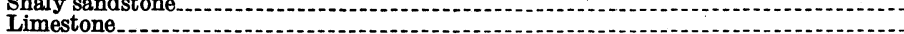 & $\mathbf{5}$ & $\begin{array}{l}92 \\
93\end{array}$ \\
\hline Brown sandstone with partings. & 1 & 94 \\
\hline Limestone with dark shale & & \\
\hline
\end{tabular}

For some distance downstream from the spring area luxuriant mesquite and salt grass suggest the presence of the water table near the surface, but in the lower part of the reservoir site there is a notable scarcity of vegetation that indicates shallow water, which is possibly due to the stony character of the soil as well as to the absence of ground water. Rocky Arroyo, which drains a large region, is dry and without indications of ground water in the lower part of its course, even to its mouth. To determine the ground-water conditions west of the river in this part of the reservoir site, test hole No. 2 was drilled in 1925 in sec. 2, T. 21 S., R. 25 E., about 11/4 miles west of Pecos River and about 1,000 feet north of Rocky Arroyo, at an elevation of 3,260 feet. This hole is 100 feet deep and struck large supplies of water at depths of 25 and 65 feet. The water from both horizons rose to a level of 15 feet below the surface, or to an elevation of 3,245 feet, which is about 20 feet above the level of the 
Major Johnson Spring and about 40 feet above the river level at the mouth of Rocky Arroyo. (See pp. 33-35, pl. 1, and figs. 1 and 2.)

At least eight test holes had been sunk at the No. 3 dam site prior to the present investigation-six in 1905, ranging between 20 and 61 feet in depth, and two in 1922, both of which were 125 feet deep. The sections of these holes, with reference to the surface, river level, and elevation above sea level, are given in Plate 2, taken from the Bonstedt and Debler report. The available logs contain several entries concerning porous or honeycombed limestone in which the water that was used in drilling was lost. In hole No. 5 of 1905 , which was 61 feet deep and was started at an elevation of 3,198 feet, or barely 10 feet above river level, the water was lost at a depth of 32 feet, and porous limestone was reported between depths of 28 and 36 feet and again at 47 feet. In both of the holes put down in 1922 honeycombed limestone was reported at various depths (pl. 2 ). The $\log$ book shows that in No. 1 , which was started at an elevation of 3,197 feet, water was lost in drilling at depths of $24,29,42$, and 78 feet, and perhaps at lower levels. The following statement in regard to these holes was made by Bonstedt and Debler, who were associated with this work: "Drilling developed the existence of extensive bodies of cavernous limestone in which loss of water was found to be excessive."

In order to obtain more definite information as to the groundwater conditions at the dam site a test hole (No. 1, pp. 30-33, pl. 1, figs. 1 and 2) was drilled in 1925 at an elevation of 3,202 feet. It extends to a depth of 152 feet. The first ground water was struck between depths of 24 and 26 feet and stood 24.5 feet below the surface, or at an elevation of about 3,176 feet, which is 10 to 15 feet below the river level at the dam site. Water struck at some greater depth in this hole, probably between 74 and 76 feet, was found to have a static head 72 feet below the surface, or at an elevation of 3,130 feet, which is about 60 feet below the river level at the dam site.

Dagger Draw.-Dagger Draw drains into Pecos River from the east, as shown in Figure 1. It reaches the river about 2 miles downstream from the No. 3 dam site and near the head of the Avalon Reservoir. There are three drilled wells in this draw. The Angel well, near the line between secs. 28 and 29, T. 20 S., R. $27 \mathrm{E}$., is said to be 180 feet deep. The reference point (the top of a heavy block of wood 18 inches above the surface) is at an elevation of 3,173 feet. On July 27, 1925, the water level in the well stood 62.2 feet below the reference point, or at an elevation of about 3,111 feet. This is about 80 feet below river level at the 
No. 3 dam site and also far below the bottom of the Avalon Reservoir.

Avalon Reservoir.-The location of the Avalon Reservoir is shown in Figure 1. The bottom of the reservoir is at an elevation of about 3,158 feet and the spillway at 3,177 feet. Its capacity is about 7,000 acre-feet. At the dam there is massive limestone underlain by breccia. Small quantities of water are seeping through the joints in the limestone and from more irregular cavities in the underlying breccia. Farther up the reservoir is underlain by alluvium, conglomerate, and red beds similar to those found in the No. 3 site. As this reservoir is effectively tight, it indicates similar favorable conditions for the proposed Reservoir No. 3. However, on account of its low head of water and small size the two are not wholly comparable. The leakage at the dam under a 10-foot head indicates that the leakage through the same rock under a 70-foot head would be considerable and perhaps dangerous. Certainly extensive grouting at the dam would be necessary.

Area between Avalon Reservoir and Carlsbad.-When no water is released at the Avalon Dam only a small amount of water appears in the channel of Pecos River for a considerable distance below the dam, but before reaching Cartsbad the stream increases to about 80 second-feet, most of this water being supplied by springs between the flume, in the SE. $1 / 4$ sec. 26, T. 21 S., R. 26 E., and the Tansil power dam. (See fig. 1.) The river level is about 3,120 feet above sea level at the flume and about 3,100 feet at Carlsbad. It appears evident that this water is ground water from distant sources and not seepage out of the canals or return water from irrigation. Several second-feet are contributed to this flow by Carlsbad Spring, which is on the west bank of the river just below the flume. It is not possible with the information at hand to say just where the water from Carlsbad Spring or the other springs in this vicinity originates. In all probability at least part of it is contributed by the great catchment area to the west. On this supposition this water, and particularly that from Carlsbad Spring, must pass through the upfold of the Carlsbad limestone that lies to the west. However, it is fairly certain that in past ages the water of Pecos River has drained in part through several underground channels, and it is entirely reasonable to suppose that the springs in the river bed above Carlsbad are supplied in part from the north through such underground channels. Either postulate involyes the assumption of large underground channels in the Carlsbad limestone, which superficially presents the appearance of being a tight rock. 

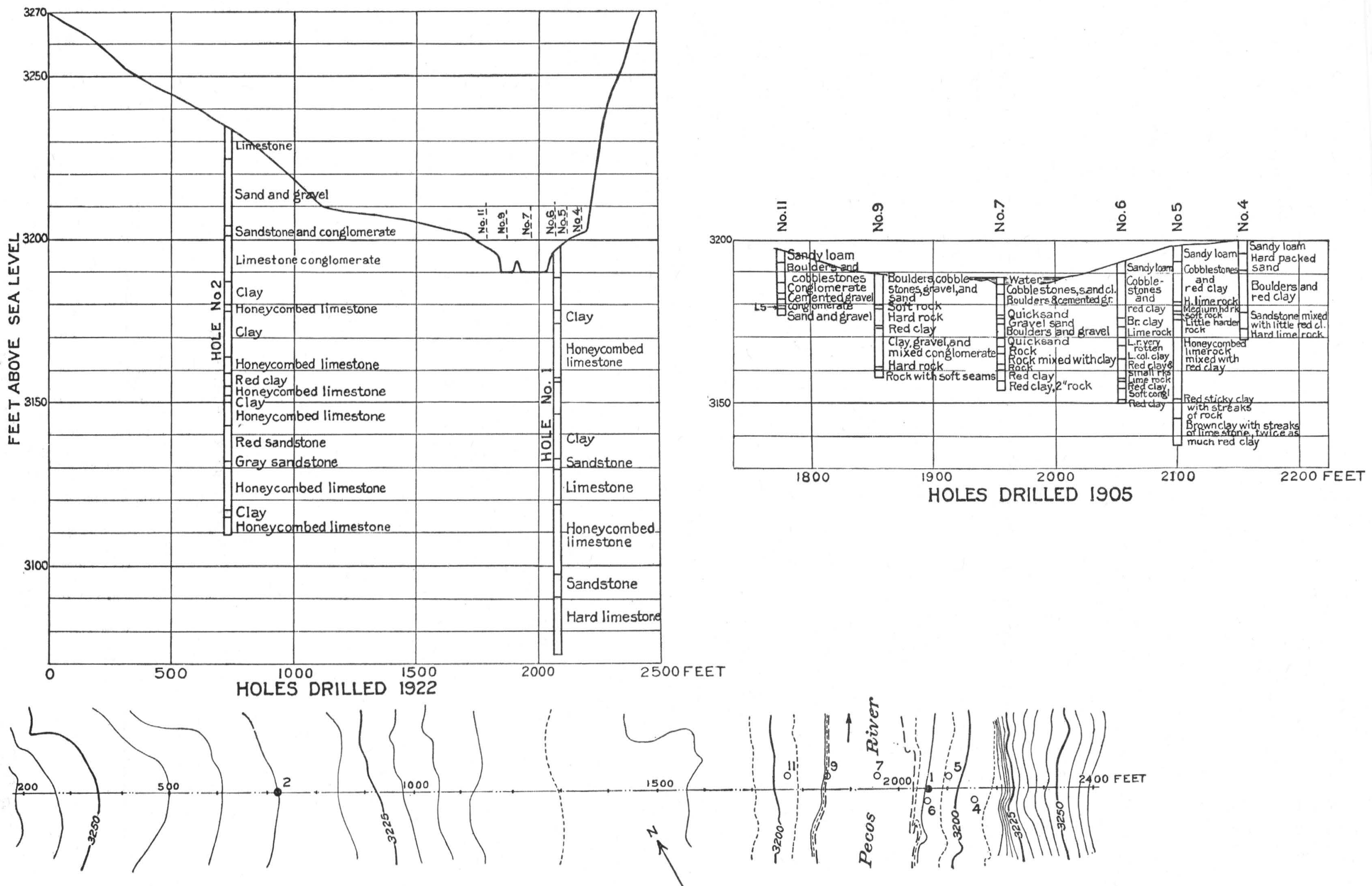

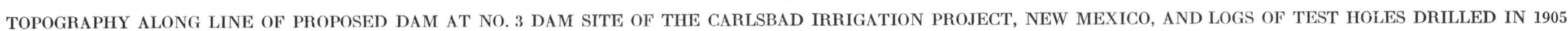
AND 1922

$94680^{\circ}-27$. (Face p. 28) 


\section{RESULTS OF TEST DRILLING}

\section{HISTORY AND PURPOSE OF TEST WELLS}

On August 3, 1925, after the field work for the present report had been completed, the drilling of four test holes was recommended, as indicated in a letter to Mr. L. E. Foster, superintendent of the Carlsbad project. This recommendation was made in order to determine more definitely the position of the water table and the ground-water conditions in the reservoir site and to ascertain whether there is unsaturated cavernous rock in the reservoir site below the level of the river. The letter written to Mr. Foster is as follows:

As I suggested to you in our conversation, it will be necessary to obtain some information as to the position of the ground-water table in and near the proposed Reservoir No. 3 before a recommendation can properly be made in regard to this project. For this purpose four test holes should be sunk at the following locations:

No. 1. At the dam site, as near as possible to hole No. 5 drilled in 1905 and No. 1 drilled in 1922.

No. 2. In sec. 2, T. 21 S., R. 25 E., north of Rocky Arroyo, about 11/4 miles up the arroyo from its mouth and about one-fifth mile north of the arroyo; about at elevation 3,260 feet.

No. 3. Near the northwest corner of sec. 36, T. 20 S., R. $26 \mathrm{E}$.

[This hole was drilled about a mile north of this location, in the NE. $1 / 4$ sec. 26, T. 20 S., R. 26 E.]

No. 4. On or near the NW. $1 / 4$ NE. $1 / 4$ sec. 20, T. 20 S., R. 26 E., one-half to three-fourths mile west of the large spring on the Major Johnson place, at the 3,260-foot elevation or slightly higher.

These holes can be drilled with an ordinary fairly heavy portable solid-tool percussion rig, such as is used in drilling water wells a few hundred feet deep. The holes should preferably be 6 inches in diameter and should not be less than 4 inches in diameter at the bottom. They need not be cased unless it should be found necessary to use casing in order to sink the hole to the required depth. The holes should be not less than 150 feet deep and should be carried to a depth of as much as 250 feet if this appears necessary to determine conclusively the ground-water conditions.

The driller should keep a $\log$ and should save samples of drillings every 20 feet, or whenever the formation changes. The purpose of this drilling is, however, not primarily to determine the nature of the rock but to ascertain the position of the water table and the ground-water conditions in relation to the river and the proposed reservoir.

At intervals of 20 feet, or whenever the formation changes, the following tests should be made under the personal supervision of an engineer of the Bureau of Reclamation:

After the tools have been withdrawn and the hole has been cleaned out, determine whether the hole is still dry or whether ground water has been struck.

If the hole is still dry, run water into it to determine whether the rock is tight or will take in water. The water for this purpose can probably be sup- 
plied most conveniently from a tank wagon. If the hole takes water, make and record observations as to the quantity of water put into the hole and the time required for it to escape.

Obviously if the rock is tight and not waterbearing, it will be desirable to continue drilling until permeable rock is struck which will either take water or yield water.

After the ground water has been struck, the depth to the water level in the well should be measured, and then water should be withdrawn for some time with a good bailer and observations should be made as to length of time the bailing was continued, rate at which water was withdrawn, and temporary draw down in the water level produced by the bailing. Drilling should, if possible, be continued to a considerable depth after water has been struck, and tests should be made at intervals of 20 feet, or whenever there is a notable change in the conditions.

The elevation of the top of the hole should be determined by instrumental leveling. Depths of the hole and depths to the water level in the hole should be measured from the same reference point. The elevations should, of course, be referred to the same datum as was used on the contour map of the reservoir site.

The elevations should be determined of the Angel well, situated west of the railroad in the Dagger Draw, and the well at the cement mill at Globe station. The reference point of the Angel well is the top of the wooden block that rests on the casing and supports the pump pipe. As soon as possible the depth to the water level in the mill well should be measured from a reference point whose elevation is determined.

Drilling operations were begun September 27, 1925, and were completed November 22, 1925. The data obtained from the test holes are given on the following pages, condensed from a manuscript report prepared by Mr. Yates. A log of the materials encountered in the holes was kept by the driller, and samples saved by him have been examined by Mr. Bryan. All the tests were carefully supervised and observed by Mr. Yates. The measurements of depth to the water level were made with a float and steel tape.

\section{RECORDS OF TEST HOLES}

By J. R. YATES

[Descriptions of samples and geologic comments by Kirk Bryan]

HOLE NO. 1

Location, on the middle line of the No. 3 dam site, 120 feet south of the river bank.

Depth, 152 feet.

Drilling begun October 8, 1925 ; completed October 18, 1925.

Elevation of top of hole, 3,202 feet; of bottom, 3,050 feet. 
[Alluvium, 0 to 42 feet; Carlsbad limestone, 42 to 152 feet; cavernous to depth of 106 feet]

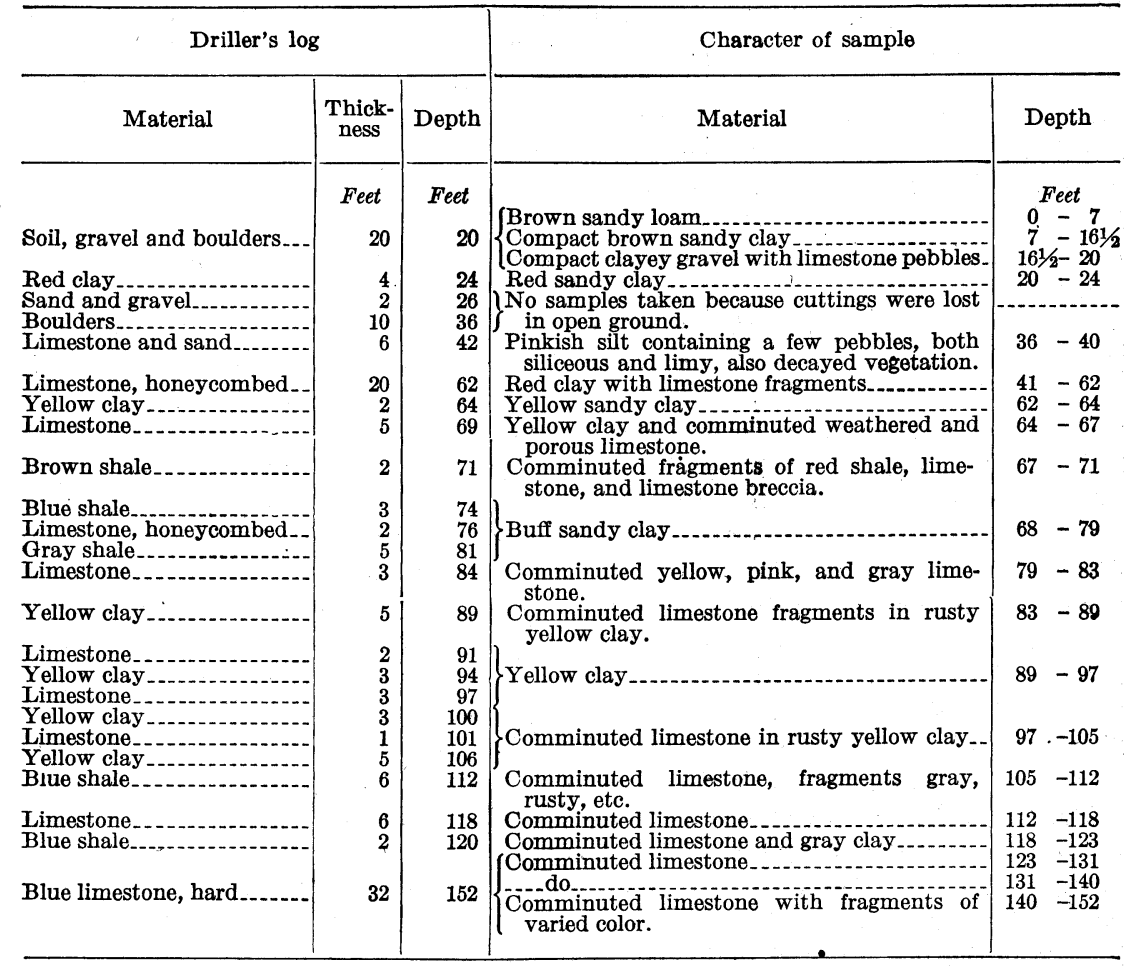

It is obvious from a consideration of this $\log$ that the hole penetrated alluvium and possibly part of the limestone conglomerate for 42 feet. The lower part of this material is sufficiently impervious to prevent downward seepage from the river and to support the perched water table having a water level of 24 feet 6 inches that is described below, under the tests. Below 42 feet the hole entered the Carlsbad limestone, which for 64 feet is weathered and apparently contains caverns full of clay. The cavernous condition of the limestone explains the discrepancies in the logs of adjacent holes drilled in 1905 and 1922 (shown diagrammatically in pl. 2). Below 106 feet the Carlsbad limestone is but little affected by solution and doubtless forms the tight floor which supports the water table that, as shown in the tests, has a level of $\mathbf{7 2}$ feet below the surface. The cavernous condition of the upper part of the limestone at this place would be a menace to the reservoir, for when it was full the movement of water through this area would be greatly increased. The easily eroded clay would be readily washed out of these caverns, leaving large openings for the passage of water under the dam.

First water test, October 10: Depth of hole, 20 feet; diameter of hole, 10 inches ; casing, none; water level, none, dry hole. Water was poured into the hole, and the depth to the water level in the hole was then measured. At the first measurement the water level stood 7 feet below the surface, and one hour later it stood 8 feet 6 inches below the surface. Eight-inch casing was then set to the depth of 20 feet to prevent caving, and drilling was resumed. The $94680^{\circ}-27-3$ 
first ground water was struck between 24 and 26 feet, but drilling was continued to 36 feet to obtain a sufficient depth of water to submerge the bailer.

Second water test, October 11: Depth of hole, 36 feet; diameter of hole, 10 inches ; casing, 8-inch to 20 feet; water level, 24 feet 6 inches below surface. A test was made with a bailer having a capacity of 19 gallons. In a period of 10 minutes the bailer was filled and removed twenty-two times, giving a withdrawal of 418 gallons, or about 42 gallons a minute. The water level was 24 feet 6 inches below the surface before the bailing was begun and was found to be at essentially the same level immediately after the bailing was stopped. Drilling was continued to 40 feet, and 8-inch casing was inserted to this depth. The drilling was then carried to 65 feet, when it was found that the water had not been successfully cased off. Casing $65 / 8$ inches in inside diameter was inserted to 65 feet and was set on limestone below 2 feet of impervious yellow clay, but this casing also failed to shut out the water. Drilling was resumed, and the casing was carried to 103 feet. About 10 feet of red impervious clay was placed inside the casing. Later the casing was driven to 107 feet, the clay was drilled out, and the drilling was carried to 111 feet.

Third water test, October 16: Depth of hole, 111 feet; diameter of hole, 6\% inches; casing, 8-inch to 41 feet, 6\%-inch to 107 feet; water level, 24 feet 6 inches below surface. The well was bailed for 15 minutes, and during that period the water level in the hole was lowered from 26 feet 4 inches to 108 feet below the surface. One hour later the water level still stood 108 feet below the surface, indicating that the outside water was completely cased off. Drilling was continued to 118 feet, when the water rose in the hole to the old level of 24 feet 6 inches below the surface. Drilling was continued to 131 feet, the 8-inch casing was pulled, and more clay was placed above the packer at 107 feet.

Fourth water test, October 17 : Depth of hole, 131 feet; diameter of hole, 6\% inches; casing, 6\% $\%$-inch to 107 feet; water level, 24 feet 6 inches below surface. Before the bailing was begun the water level stood 26 feet 4 inches below the surface. The bailing was continued 10 minutes, and the water level was thereby lowered to 75 feet below the surface. Four and a half hours later another measurement showed that the water level had gone down to 76 feet 6 inches. This test was made to ascertain the leak around the packer set at 107 feet, as it was thought at the time that the water came from the 25-foot level. It was not thought advisable to bail out the water below the 75-foot level on account of the pressure of the outside water on the packer. Later tests, however, seemed to show that this water came from 72 feet and that the water that was lost was absorbed in the hole between the end of the packer at 107 feet and the bottom of the well at 131 feet. Evidently the water was temporarily cased off during this test. Drilling was continued to 140 feet. The last slush bailed out showed tints of red clay, which indicated that water was leaking around the packer at 107 feet.

Fifth water test, October 17: Depth of hole, 140 feet; diameter of hole, 65/8 inches; casing, 65-inch to 107 feet. The water was bailed down to 96 feet. Bailing was then stopped and measurements of the depth to the water level were made as follows:

Measurements of depth to water level in fifth test

\begin{tabular}{lr|r} 
& Feet &
\end{tabular}$\quad \begin{array}{r}\text { Feet } \\
1.00 \mathrm{p} . \mathrm{m} . \text { (end of bailing) } \\
1.15\end{array}$


Sixth water test, October 17: At 3 p. m. more red clay was placed around the casing, and another test was made, as follows:

Measurements of depth to water level in sixth test

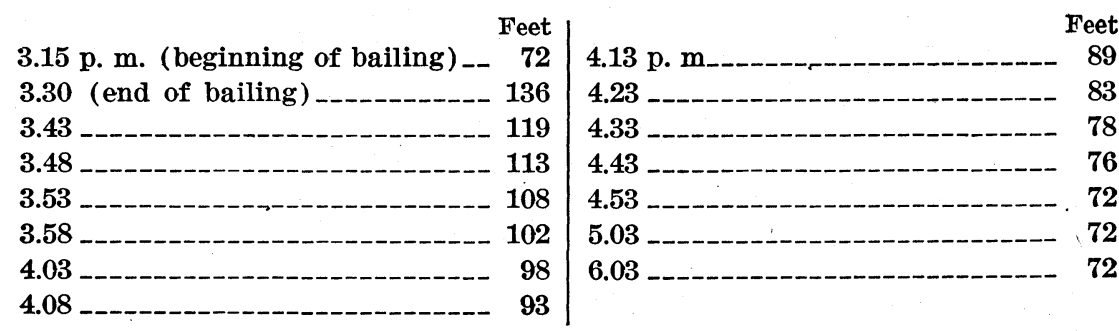

In this test, as in the previous one, the water evidently rose to the 72-foot level as a result of leakage around the packer at 107 feet. Drilling was continued to 142 feet. The water level in the hole was 93 feet below the surface at $9.30 \mathrm{p}$. $\mathrm{m}$. and 80 feet at $7.30 \mathrm{a}$. $\mathrm{m}$. the next morning, no drilling being done in the meanwhile. This slow rise was probably due to a slight leak around the packer. Drilling was then carried to 152 feet.

Seventh water test, October 18: Depth of hole, 152 feet; diameter of hole, 65 inches; casing, 65/8-inch to 107 feet.

Measurements of depth to water level in seventh test

\begin{tabular}{|c|c|}
\hline Feet & \\
\hline 11.30 a. m. (beginning of bailing) & 12.10 p. $\mathrm{m}$ \\
\hline 11.45 (end of bailing) & 12.15 \\
\hline 11.53 & 12.20 - \\
\hline 11.55 & 1.20 \\
\hline 12.00 noon & 2.20 \\
\hline 12.05 p. m & \\
\hline
\end{tabular}

As in the fifth and sixth tests, the water evidently rose to the 72-foot level as a result of leakage around the packer. In making the sixth and seventh tests water could be plainly heard pouring into the hole until the water level had risen to the packer at 107 feet.

The last four tests show that there is a second body of ground water with a static head of 72 feet below the top of the hole. As this water was tapped before the first water at the 25-foot level was cased off, its exact horizon can not be determined. However, the $\log$ of the hole indicates that the waterbearing stratum probably lies between 74 and 76 feet. The water level still remained at the 72-foot level on October 25, a week after the last test had been made. It is evident, therefore, that the first water was bridged off from the second at the time the 8-inch casing was pulled. The fourth test seems to indicate that the second body of ground water is also perched.

HOLE NO, 2

Location, sec. 2, T. 21 S., R. 25 E., about $11 / 4$ miles west of Pecos River and about 1,000 feet north of Rocky Arroyo, at an elevation of 3,260 feet.

Depth, 100 feet.

Drilling begun October 23, 1925 ; completed November 3, 1925.

Elevation of top of well, 3,260 feet; of bottom, 3,160 feet. 
Record of hole No. 2

[Alluvium, 0 to 18 feet; Castile formation or Carlsbad limestone, 18 to 65 feet; Carlsbad limestone, 65 to 100 feetl

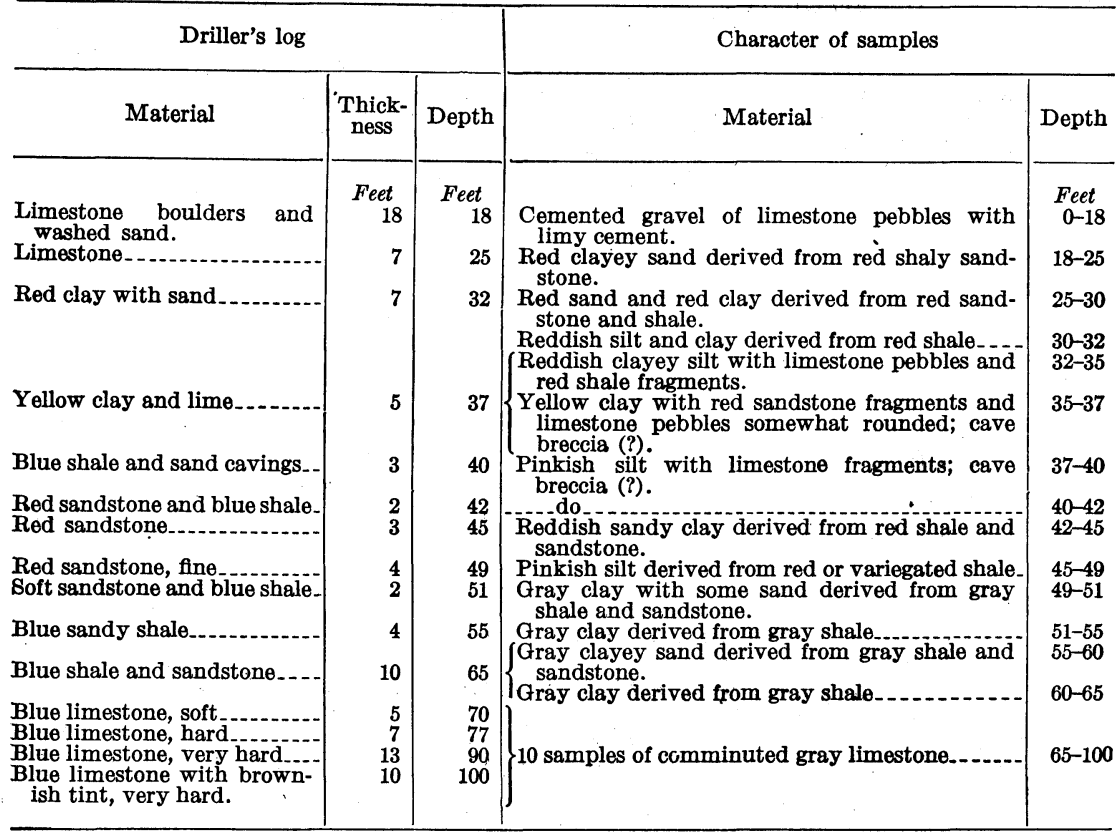

This hole is adjacent to Rocky Arroyo, and the log shows that it passes through 18 feet of alluvium of the gravelly type characteristic of this vicinity. The next 57 feet consists of sandstone and shale, of which the upper part is red and the lower part gray. This material resembles parts of the Castile formation, and it is possible that a concealed outlier of this formation lies below the alluvium and terrace deposits of Rocky Arroyo. On the other hand, it may be that this $\mathbf{5 7}$ feet of sandstone and shale is part of a lens within the Carlsbad limestone, as that formation crops out at a higher elevation on the adjacent hills. The limestone encountered in the hole from 65 to 100 feet is similar in every way to that observed in outcrops of the Carlsbad limestone.

Hole No. 2 was spudded in October 23. After three days of slow progress the first hole was abandoned at $\mathbf{1 7}$ feet on account of caving boulders, and a second hole was begun October 26. In the second hole the boulders were successfully cased off with 13 feet of 8-inch casing, and drilling was continued to 20 feet, when the first test was made.

First water test, October 27-28: Depth of hole, 20 feet; diameter of hole, 8 inches; casing, 8-inch to 13 feet; water level, none, dry hole. The hole was filled by pouring in water. The water level went down only 6 inches in 12 hours. The drilling was then carried to 36 feet. The first water, struck between 24 and 26 feet, rose within 15 feet of the surface. The hole was cased to 20 feet.

Second water test, October 28: Depth of hole, 36 feet; diameter of hole, 8 inches ; casing, 8-inch to 20 feet; water level, 15 feet below surface. In a test of 15 minutes an 18-gallon bailer was filled and withdrawn thirty-five times, giving a withdrawal of 630 gallons, or 42 gallons a minute. Before the test 
was begun the water level was 15 feet below the surface; at the end it was 16 feet; and one minute later it was back to about the 15-foot level. The hole was drilled to 42 feet, and $65 / 8$-inch casing was inserted with a casing shoe to 42 feet and was set on sandstone and blue shale, these being the first strata on which the casing could be set with reasonable assurance of shutting off the water. The water inside the casing was bailed out, and two hours later the hole was found to be dry. Drilling was carried to 60 feet in the hole, from which the outside water remained completely cased off. The slush and about 3 feet of water used in drilling were removed, and then the third test was made.

Third water test, October 30-31: Depth of hole, 60 feet; diameter of hole, $65 \%$ inches; casing, 8 -inch to 20 feet, $6 \%$-inchs to 42 feet; water level, none, dry hole. Water was poured into the hole until it was filled to a level 20 feet below the surface. After an interval of 10 hours the water level was still 20 feet below the surface, showing that the rock between 42 and 60 feet was impervious. Drilling was continued, and the second ground water was struck at 65 feet. This water rose within 15 feet of the top of the hole, or to the same level as the water found at 25 feet.

Fourth water test, October 31: Depth of hole, 65 feet; diameter of hole, 6\% inches; casing, same as in third test; water level, 15 feet below surface. The water level could not be lowered noticeably with a small bailer, such as would go inside the $6 \%$-inch casing, although water was removed at the rate of 20 gallons a minute. Drilling was continued to 100 feet. From 70 to 100 feet the rock was very hard blue limestone with traces of iron.

HOLE NO. 3

Location, 100 feet south and 100 feet west from the northeast corner of sec. 26 , T. 20 S., R. 26 E.

Depth, 206 feet.

Drilling begun September 27, 1925 ; completed October 4, 1925.

Elevation of top of hole, 3,305 feet; of bottom, 3,099 feet.

Record of hole No. 3

[Soil, 0 to 3 feet; Castile formation, 3 to 205 feet]

\begin{tabular}{|c|c|c|c|c|}
\hline \multicolumn{3}{|c|}{ Driller's log } & \multicolumn{2}{|l|}{ Character of samples } \\
\hline Material & $\begin{array}{c}\text { Thick- } \\
\text { ness }\end{array}$ & Depth & Material & Depth \\
\hline & Feet & Feet & & Feet \\
\hline Soil & & & No samples taken & - n \\
\hline Gypsum & & 15 & do do & \\
\hline Red clay..... & 29 & 44 & Red sandy clay with minute crystals of gypsum & $\begin{array}{l}15-30 \\
30-44\end{array}$ \\
\hline Gypsum rock.... & 16 & 60 & Gypsum and red clay derived from impure gypsum & $44-60$ \\
\hline Do & $\begin{array}{l}20 \\
16\end{array}$ & $\begin{array}{l}80 \\
96\end{array}$ & $\begin{array}{l}\text { White and red gypsum } \\
\text { Gypsum and red clay derived from gypsum beds }\end{array}$ & $\begin{array}{l}60-80 \\
80-96\end{array}$ \\
\hline Red clay & 14 & 110 & $\begin{array}{l}\text { with layers of clay. } \\
\text { Red clay with fragments of gypsum }\end{array}$ & $96-110$ \\
\hline Red beds and gravel(?) & $\begin{array}{l}14 \\
10\end{array}$ & 120 & Red clayey gravel derived from red shale and cave & $110-133$ \\
\hline Lime and red beds..... & 13 & 133 & breccia. & \\
\hline Red clay beds.................. & $\begin{array}{r}8 \\
29\end{array}$ & $\begin{array}{l}141 \\
170\end{array}$ & Red sandy clay. & $\begin{array}{l}133-141 \\
141-170\end{array}$ \\
\hline Gypsum rock an & 10 & 180 & Broken fragments of massive gypsum & $170-180$ \\
\hline Gypsum rock, ha & 5 & 185 & Finely comminuted gypsum & $180-185$ \\
\hline Gypsum rock, soft. & 12 & 197 & $\left\{\begin{array}{l}\text { Puverulent gypsum } \\
\text { Clayey gypsum }\end{array}\right.$ & $\begin{array}{l}185-190 \\
190-194\end{array}$ \\
\hline & & & Pulverulent gypsum and anhydrite & $194-197$ \\
\hline Gypsum rock, hard.- & 8 & 205 & $\begin{array}{l}\text { Anhydrite, with minor quantity of gypsum probably } \\
\text { derived from rock above. }\end{array}$ & $197-205$ \\
\hline
\end{tabular}


Except for 3 feet of soil at the top, this hole is entirely in the Castile formation, in which it encountered 89 feet of gypsum and 8 feet of anhydrite. So large a proportion of gypsum in this formation would not be suspected at the outcrops in the bluffs along Pecos River. Near the river the soluble gypsum beds have doubtless been largely dissolved. Moreover, the existing beds of gypsum are largely concealed by talus or slope wash. As will be noted in the account of the tests, the greatest loss of water took place at a level between 110 and 120 feet. This phenomenon is explained by the sample taken between 110 and 133 feet, for it consists of red clayey gravel that can be interpreted only as a mixed mass of fragments of shale and limestone such as would accumulate in a cave. Evidently this cave breccia does not completely fill these caves, which are capable of carrying off considerable quantities of water.

This hole was drilled 10 inches in diameter from top to bottom, and no casing was used. No ground water was encountered, but 12 tests were made by pouring water into the hole and measuring the depth to the water level thus produced in the hole.

First water test, September 28: The first test was made when the hole had reached a depth of 20 feet. Water was poured into the hole until it was filled. In six hours the water level receded 4 feet, probably owing to absorption by the top soil.

Second water test, September 28: The second test was made when the hole was still 20 feet deep and was virtually a duplicate of the first. The hole was refilled, and the water level went down 4 feet in four hours. The drilling was then carried to 40 feet.

Third water test, September 28: When the hole was 40 feet deep it was filled with water. The water level went down 1 foot in about one hour. Drilling was then carried to 60 feet.

Fourth water test, September 28: The 60-foot hole was filled with water. The water level went down 1 foot 6 inches in three hours. Drilling was carried to 65 feet.

Fifth water test, September 28-29: The 65-foot hole was filled within 5 feet of the top, and the water level was observed to go down 4 feet in 131/2 hours. Drilling was carried to 85 feet.

Sixth water test, October 29: The 85-foot hole was filled within 7 feet of the top, and the water level was observed to go down 3 feet in one hour. Drilling was carried to 130 feet.

Seventh water test, September 29: The 130-foot hole was flled to a level 80 feet below the surface. The water level went down 10 feet in one hour. The leak was believed to be between 110 and 120 feet. Drilling was carried to 160 feet.

Eighth water test, September 29: The 160-foot hole was filled to a level 100 feet below the surface. The water level went down 20 feet in one hour, the leakage presumably being between 110 and 120 feet. The water did not recede below the 120 -foot level in a period of $171 / 2$ hours. Drilling was carried to 200 feet.

Ninth water test, October 2: The 200-foot hole was filled to a level 150 feet below the surface. The water level receded 1 foot in about one hour. After drilling to about 206 feet, the swivel came off the drill stem and left the tools at the bottom of the hole. After various unsuccessful attempts had been made to recover the tools, three more water tests were made with the tools in the hole.

Tenth water test, October 4-5: The hole was about 206 feet deep. At 6 p. m. October 4 work was begun in filling it from about the 151-foot level. By 7 
p. m. 700 gallons had been placed in the well, but no measurement of the depth to the water level was made. At $10 \mathrm{a}$. m. October 5 the water level stood 137 feet below the surface. The drillers reported that the water receded very fast down to 120 feet.

Eleventh water test, October 5: The test was begun at 10.15 a. m., when the water in the hole stood about 137 feet below the surface. Between 10.15 and 10.30 about 300 gallons of water were poured into the hole, and at 10.31 the water level was 102 feet below the surface. The water level then went down and was 112 feet below the surface at 10.36, 117 feet at 10.46, and 122 feet at 11.06.

Twelfth water test, October 5: At 11.10 a. m. the water level was about 122 feet below the surface. Between 11.10 and 11.30 about 300 gallons of water was added. The water level was 92 feet below the surface at 11.32, 105 feet at 11.37, 112 feet at 11.42, 117 feet at $12.02 \mathrm{p}$. m., 122 feet at $12.22,124$ feet at 12.42, 127 feet at 1.22, and 137 feet at 6 . It is believed that the main leak was between 110 and 120 feet. The hole was then abandoned.

HOLE NO. 4

Location, in the NE. $1 / 4$ NE. $1 / 4$ sec. 20 , T. 20 S., R. 26 E., one-half mile west of large spring on Pecos River.

Depth, 132 feet.

Drilling begun November 5, 1925 ; completed November 22, 1925.

Elevation of top of hole, 3,260 feet; of bottom, 3,128 feet.

\section{Record of hole No. 4}

[Alluvium, 0 to 35 feet; Seven Rivers gypsiferous member of Chupadera formation, 35 to 132 feet]

\begin{tabular}{|c|c|c|c|c|}
\hline \multicolumn{3}{|l|}{ Driller's log } & \multicolumn{2}{|l|}{ Character of samples } \\
\hline Material & $\begin{array}{l}\text { Thick- } \\
\text { ness }\end{array}$ & Depth & Material & Depth \\
\hline Soil, sandy at base. & ${ }_{6}^{\text {Feet }}{ }_{6}$ & ${ }_{6}^{\text {Feet }}{ }_{6}$ & Soil & $\begin{array}{l}\text { Feet } \\
0-6\end{array}$ \\
\hline $\begin{array}{c}\text { Conglomerate loosely cemented } \\
\text { together }\end{array}$ & 19 & 25 & $\left\{\begin{array}{l}\text { Buff-colored clayey gravel, angular limestone } \\
\text { pebbles }\end{array}\right.$ & $6-10$ \\
\hline $\begin{array}{l}\text { Sandrock and conglomerate, } \\
\text { moderately hard. }\end{array}$ & 10 & 35 & Yellow sandy cemented gravel & $25-35$ \\
\hline Formation open & 26 & 61 & No samples could be collected & \\
\hline $\begin{array}{l}\text { Sandrock, reddish and medium } \\
\text { hard. }\end{array}$ & 5 & 66 & $\begin{array}{l}\text { Pink silty sand derived from red clayey sand- } \\
\text { stone. }\end{array}$ & $61-66$ \\
\hline $\begin{array}{l}\text { Open formation } \\
\text { Open cavern }\end{array}$ & $\begin{array}{r}26 \\
3\end{array}$ & $\begin{array}{l}92 \\
95\end{array}$ & No samples could be collected & $\cdots$ \\
\hline Sandrock, waterbearing & 6 & 101 & Pink sand derived from red sandstone.-. & $100-101$ \\
\hline Open formation & $\mathbf{9}$ & 110 & No samples could be collected............. & \\
\hline $\begin{array}{l}\text { Sandrock, soft } \\
\text { Sandrock, hard }\end{array}$ & $\begin{array}{l}7 \\
8\end{array}$ & $\begin{array}{l}117 \\
125\end{array}$ & $\begin{array}{l}\text { Fine silt derived from shale } \\
\text { Red clayey sand derived from shaly red sand- }\end{array}$ & $\begin{array}{l}110-117 \\
117-125\end{array}$ \\
\hline Conglomerate, loosely cemented. & 7 & 132 & $\begin{array}{l}\text { sink silty clay with limestone pebbles, prob- } \\
\text { ably a cave breccia. }\end{array}$ & $125-130$ \\
\hline
\end{tabular}

After penetrating 6 feet of soil this hole entered gravel that is more or less cemented. The lowest $\mathbf{1 0}$ feet of this gravel is very compact and lies upon open cavernous material that extends 25 feet to a red clayey sandstone 5 feet thick. Below this sandstone is 29 feet of similar cavernous material. The lower 3 feet of this interval was a hole that offered no obstruction to the drill. Below a second bed of red sandstone there is a similar open formation for 9 feet, and below it shale, shaly sandstone, and breccia extend to the bottom of the 
well at 130 feet. As reported by the driller the open formation contained water, the sides of the drill hole readily sloughed off, and the drill cuttings were pushed to the side into the cavities, so that no samples could be recovered. Evidently the original gypsum beds of this locality,. which were part of the Seven Rivers gypsiferous member, have been dissolved by the ground water. Thin beds of the interbedded sandstone and shale remain separated by rubbish collected in the caves.

A 10-inch hole was drilled to a depth of 20 feet. No water was struck, and no casing was inserted, but a test was made by filling the hole with water. The water level receded 2 feet in about one hour, probably owing to absorption by the top soil.

Drilling was continued to 40 feet. The first ground water was found between 28 and 30 feet and stood at a level 28 feet below the surface, but it was necessary to drill at least 10 feet below the water level before making a bailing test in order to submerge the bailer. Eight-inch casing was inserted to the depth of 21 feet, but between 21 and 40 feet there was a 10-inch uncased hole. About 350 gallons of water was run into the hole in 20 minutes without producing any noticeable rise or fall in the water level, which stood 28 feet below the surface. A bailing test was then made, with a bailer of 18 gallons capacity. This bailer was filled and removed twenty-eight times in 10 minutes, giving a withdrawal of about 500 gallons, without noticeably lowering the water level.

Drilling was then carried to 60 feet in open water-bearing material of which no cutting could be obtained, and a $6 \%$-inch casing with casing shoe was inserted to 62 feet. Drilling was carried to 85 feet, and the casing followed to 70 feet. The hole caved badly, and no cuttings could be collected. Drilling was carried to 107 feet, and 65/8-inch casing followed the drill to 97 feet with light driving. The bailer brought out only clear water with no cuttings between 85 and 107 feet, and an open cavern was found between 92 and 95 feet. The casing was set at 97 feet in sandstone, and the water was bailed out. The well remained dry for three minutes, after which water began to enter from a leak around the bottom of the casing. The casing was driven to 107 feet 2 inches. The fact that the $6 \%$-inch casing, which measured $71 / 2$ inches outside diameter over couplings, followed a 5-inch bit from 60 to 107 feet indicates that the formation is soft and without strength.

The drilling tools were then inserted, but the lip of the drill bit caught under the casing shoe at the end of the casing. The casing was raised 3 feet with jacks, but this operation did not release the drill bit. Pulley blocks and "gin" pole were rigged up to pull the casing. It was started with jacks assisted by the machine but was pulled apart at the first joint, 22 feet below the surface. The final pull was made with the jacks directly on the cable to which the tools were attached, and the tools were recovered.

It was discovered that a dent had been made in the casing near the bottom. Hence a string of old tools was made up with 4-inch bit and jars. The tools uncoupled in the hole four times in one day but were each time recovered within a few minutes after being lost. Drilling was carried to 109 feet, and 100 pounds of plaster of Paris was placed in the hole for the purpose of cementing off the water at the end of the casing. The setting time of plaster under water was considered to be one hour, but the plaster was left undisturbed overnight. An attempt was then made to bail out the hole, and it was found that the water had not been cemented off by the plaster. When the bailer was inserted to the bottom of the hole it was found that the plaster had es- 
caped into the open formation. Only a very small portion of the plaster was recovered by the bailer.

When the drill bit was placed in the hole it went down to a depth of 109 feet. Drilling was continued to 132 feet with the 5-inch bit and stem that were used in the first 107 feet, and the first part of this work was in caving material. The tools became wedged in the casing three times and were each time recovered by pulling with the jacks. The hole caved below the bottom of the casing. The cavings were bailed out, and a liberal sample of the formation was obtained. To drill deeper than 132 feet would have required a liner of not less than 150 feet of 5-inch casing to case off the caving material. Upon telegraphic advice from Mr. Renick the hole was considered completed at a depth of 132 feet. The casing was not recovered, because the cost of pulling it would probably have'exceeded its value. 
